\title{
Use of Mass Spectrometry to Profile Peptides in Whey Protein Isolate Medium Fermented by Lactobacillus helveticus LH-2 and Lactobacillus acidophilus La-5
}

\author{
Eman Ali ${ }^{1,2}$, Søren D. Nielsen ${ }^{3}$, Salah Abd-El Aal ${ }^{4}$, Ahlam El-Leboudy ${ }^{5}$,Ebeed Saleh ${ }^{1}$ and \\ Gisèle LaPointe ${ }^{2 *}$ \\ ${ }^{1}$ Food Hygiene Department, Faculty of Veterinary Medicine, Damanhour University, Damanhour, Egypt, ${ }^{2}$ Canadian Research \\ Institute for Food Safety, University of Guelph, Guelph, ON, Canada, ${ }^{3}$ Department of Food Science, Faculty of Science and \\ Technology, Aarhus University, Aarhus, Denmark, ${ }^{4}$ Food Control Department, Faculty of Veterinary Medicine, Zagazig \\ University, Zagazig, Egypt, ${ }^{5}$ Food Hygiene Department, Faculty of Veterinary Medicine, Alexandria University, Alexandria, \\ Egypt
}

OPEN ACCESS

Edited by:

Laurent Dufossé,

Université de la Réunion, France

Reviewed by:

Yannick Fleury,

Université de Bretagne Occidentale, France

Elvira Maria Hebert

National Council for Scientific and

Technical Research

(CONICET), Argentina

${ }^{*}$ Correspondence:

Gisèle LaPointe

glapoint@uoguelph.ca

Specialty section

This article was submitted to

Food Microbiology,

a section of the journal

Frontiers in Nutrition

Received: 22 October 2018 Accepted: 06 September 2019 Published: 15 October 2019

Citation:

Ali E, Nielsen SD, Abd-El Aal S, El-Leboudy A, Saleh E and LaPointe G (2019) Use of Mass Spectrometry to Profile Peptides in Whey Protein Isolate Medium Fermented by Lactobacillus helveticus $\mathrm{LH}-2$ and Lactobacillus acidophilus La-5.

Front. Nutr. 6:152.

doi: 10.3389/fnut.2019.00152
Peptides in the 3-kDa ultrafiltrate of fermented whey protein isolate (WPI) medium could be responsible for the antivirulence activity of Lactobacillus he/veticus LH-2 and Lactobacillus acidophilus La-5 against Salmonella Typhimurium. Non-fermented and fermented media containing 5.6\% WPI were fractionated at a $3 \mathrm{kDa}$ cut-off and the filtrate was analyzed by mass spectrometry. The non-fermented WPI medium contained 109 milk derived peptides, which originated from $\beta$-casein (52), $\alpha$ s1-casein (22), as2-casein (10), $\kappa$-casein (8), and $\beta$-lactoglobulin (17). Most of these peptides were not found in the fermented media, except for 14 peptides from $\beta$-casein and one peptide from $\alpha_{\mathrm{s} 2}$-casein. Database searches confirmed that 39 out of the 109 peptides had established physiological functions, including angiotensin-converting-enzyme (ACE) inhibitory, antioxidant, antimicrobial, or immunomodulating activity. A total of 75 peptides were found in the LH-2 cell free spent medium (CFSM): 54 from $\beta$-casein, 14 from $\mathrm{k}$-casein, 4 from $\beta$-lactoglobulin and 3 from $\alpha$ s2-casein. From these peptides, 19 have previously been associated with several categories of bioactivity. For La-5 CFSM, a total of 15 peptides were sequenced: 8 from $\beta$-casein, 5 from $\alpha$ s1-casein, 2 from $\beta$-lactoglobulin. Only 5 of these have previously been reported as having bioactivity. Many of the peptides remaining in the fermented medium would contain low-affinity residues for oligopeptide binding proteins and higher resistance to peptidase hydrolysis. These properties of the sequenced peptides could explain their accumulation after fermentation despite the active proteolytic enzymes of LH-2 and La-5 strains. Down-regulated expression of hilA and SsrB genes in $S$. Typhimurium was observed in the presence of La-5 and LH-2 CFSM. Downregulation was not observed for the Salmonella oppA mutant strain exposed to the same CFSM used to treat the S. Typhimurium DT104 wild-type strain. This result suggests the importance of peptide transport by $S$. Typhimurium for down regulation of virulence genes in Salmonella.

Keywords: bioactive peptides, probiotic, whey, Salmonella, virulence, gene expression 


\section{INTRODUCTION}

Salmonella enterica subsp. enterica serovar Typhimurium is considered a major foodborne pathogen with public health and economic concerns. This foodborne pathogen has developed resistance against a broad range of antibiotics (1). Alternative approaches to control this pathogen depending on the inhibition of virulence gene expression and stimulation of the host immune system have been suggested. These approaches cause less stress to bacterial cells to avoid the development of resistant clone (2). A Type III Secretion System (TTSS) is used by $S$. Typhimurium to inject and translocate effector proteins into host cells for adherence, attachment and invasion (3). Salmonella pathogenicity island I (SPI1) controls the production and activity of the Type III secretion system which enables the membrane ruffling process, in which the epithelial cell cytoskeleton is rearranged to engulf the Salmonella into cytoplasmic vacuoles (4). The gene hilA directly controls and activates all the genes of SPI1 for invasion (5). The gene $s s r B$ is the main regulator of SPI2, which is responsible for systemic infection and replication of $S$. Typhimurium inside macrophages and epithelial cells (6). Down regulation of these virulence genes would be an alternative way to reduce the severity of Salmonella infection.

Milk proteins are a major source of bioactive peptides (7). Milk derived peptides may have effects on the digestive, immune, cardiovascular and nervous systems (8). Previous studies have suggested that bioactive metabolites produced by $L$. helveticus LH-2 and L. acidophilus La-5 could down-regulate virulence gene expression in both Salmonella and E. coli O157:H7 after growth in chemically defined media and milk (9-12).

Bioactive peptide production in lactic acid bacteria (LAB) is the result of the balance between proteolytic activity and peptide consumption (13). The proteolytic system of LAB consists of proteinases and peptidases which initially cleave milk proteins to oligopeptides, specific transport proteins which transport smaller peptides and amino acids across the cytoplasmic membrane and intracellular peptidases, which further degrade these peptides to small peptides and amino acids (14). The considerable amino acid auxotrophy of L. helveticus and L. acidophilus is consistent with the presence of many peptidases/proteases and related transport systems for amino acids and peptides (15).

The oligopeptide-binding protein (OppA) is one of the most abundant periplasmic proteins in $S$. Typhimurium. oppA gene expression in $S$. Typhimurium is modulated by nitrogen compounds and regulates the expression of other genes such as Lrp (leucine-responsive regulatory protein) or CodY (16). Mutation in OppA in S. Typhimurium leads to losing the ability to transport muropeptides and detect the nutritional or signaling peptides (17).

In this study, the proteolytic and peptidolytic activities of LH-2 and La-5 strains in Whey Protein Isolate (WPI) are explored through genome sequencing and biochemical assays on substrates. Peptide profile analysis by mass spectrometry was conducted to understand the potential factors that lead to accumulation of antivirulence peptides in the growth media. Furthermore, the correlation between oppA gene expression and virulence gene expression in Salmonella in the presence of antivirulence peptides was investigated using a $S$. Typhimurium oppA mutant strain.

\section{MATERIALS AND METHODS}

\section{Bacterial Strains and Growth Conditions}

All bacterial strains used in this study were obtained from the Canadian Research Institute for Food Safety (CRIFS) except for the Salmonella Typhimurium oppA mutant, which was provided by Prof. Eric Brown, McMaster University. Lactobacillus helveticus LH-2 and Lactobacillus acidophilus La5 probiotic strains were grown under anaerobic conditions at $37^{\circ} \mathrm{C}$ for $48 \mathrm{~h}$ on De Man, Rogosa, Sharpe broth (MRS; Thermo Scientific ${ }^{\mathrm{TM}}$ Oxoid $^{\mathrm{TM}}$ Ottawa, ON, Canada). Salmonella Typhimurium hilA::lux and Salmonella Typhimurium ssrB::lux were grown on Luria-Bertani broth (LB; Life Technologies, Burlington, ON, Canada) supplemented with $50 \mu \mathrm{g} / \mathrm{ml}$ of ampicillin (Amp). Both constructs were grown aerobically overnight on a shaking incubator at $37^{\circ} \mathrm{C}$. S. Typhimurium DT104 and $S$. Typhimurium oppA mutant strains were grown under the same condition as $S$. Typhimurium constructs, but without Amp. Solid media preparation for all strains were carried out under the same conditions but with addition of $15 \mathrm{~g} / \mathrm{l}$ of agar and incubated under the same conditions.

\section{Preparation of $L$. helveticus $\mathrm{LH}-2$ and $L$. acidophilus La-5 Cell Free Spent Medium (CFSM)}

Whey Protein Isolate (WPI) (NZWPI 895, Caldic, Fonterra, USA) was dissolved at $5.6 \%(\mathrm{v} / \mathrm{v})$ in sterile sugar solution. Glucose or sucrose (Fisher Scientific, Ottawa, ON, Canada) at $0.5 \%(\mathrm{v} / \mathrm{v})$ were added for L. helveticus LH-2 and L. acidophilus La-5, respectively. The media were filter sterilized through $0.45 \mu \mathrm{m}$ pore-size filters (Corning, NY 14831, Germany). An overnight culture of each strain in MRS broth was washed and inoculated at $5 \%(\mathrm{v} / \mathrm{v})$ into WPI based media and incubated anaerobically at $37^{\circ} \mathrm{C}$ for $48 \mathrm{~h}$. Following growth, bacterial cells were removed by centrifugation at $15,000 \times g$ for $30 \mathrm{~min}$ at $4^{\circ} \mathrm{C}$. The supernatant was filtered through a $0.20 \mu \mathrm{m}$ pore-size filter (Corning) to obtain sterile CFSM which was subsequently freeze-dried (VirTis, Genesis, USA) for $72 \mathrm{~h}$ and stored at $-80^{\circ} \mathrm{C}$.

\section{Effect of CFSM on Gene Expression in S. typhimurium Reporter Constructs}

For initial screening of the antivirulence effects of CFSM, bioluminescent reporter strains S. Typhimurium hilA::lux and ssrB::lux (18) were used. Briefly, the luxCDABE operon from Xenorhabdus luminescens was isolated and cloned with an Amp resistance gene into a plasmid (pSB377), which was further fused with the hilA and $s s r B$ promoter regions, separately. The expression of the lux genes is controlled by these promoter regions, so that light is emitted when the gene is expressed. Each overnight culture of the constructs was diluted 1:100 with fresh LB broth with and without supplementation of $10 \%(\mathrm{v} / \mathrm{v})$ of neutralized $(\mathrm{pH} 7)$ CFSM from L. helveticus LH2 and L. acidophilus La-5, which had been reconstituted in 
sterile deionized water at 10 -fold concentration compared to the initial medium. The samples were incubated aerobically at $37^{\circ} \mathrm{C}$ with shaking for $3 \mathrm{~h}$. Luminescence was measured with the FB 12 luminometer (Berthold Detection Systems, Pforzheim, Germany). The results are presented as Relative Light Units (RLU)/OD $600 \mathrm{~nm}$.

\section{Effect of CFSM and Mixture of Synthetic Peptides on Transcription of Virulence Genes of $S$. typhimurium by RT-qPCR \\ RNA Extraction}

RNA was extracted from $S$. Typhimurium DT104 and $S$. Typhimurium oppA mutant following $3 \mathrm{~h}$ growth in fresh LB broth with and without $10 \%$ neutralized ( $\mathrm{pH}$ 7) CFSM with shaking at $37^{\circ} \mathrm{C}, 2-\mathrm{ml}$ samples were centrifugated at 5,000 $\times \mathrm{g}$ for $4 \mathrm{~min}$ at RT. The supernatant was discarded and cells were mixed with $1 \mathrm{ml}$ of RNA Protect reagent (Qiagen Inc., Mississauga, ON, Canada) and incubated for $5 \mathrm{~min}$ at RT. Cells were collected again by centrifugation at 5,000 $\times \mathrm{g}$ for $10 \mathrm{~min}$ at RT. Cell pellets were suspended in $200 \mu \mathrm{l}$ of Tris-EDTA buffer, $\mathrm{pH} 8.0$ (Fisher Scientific, Ottawa, ON, Canada), $60 \mu \mathrm{l}$ of $20 \mathrm{mg} / \mathrm{ml}$ lysozyme (Fisher Scientific) and $20 \mu \mathrm{l}$ of proteinase K (Qiagen). The suspensions were incubated at $37^{\circ} \mathrm{C}$ for $1 \mathrm{~h}$ with shaking at 450 rpm. RNeasy Plus Mini Kit (Qiagen) was used to extract RNA from all samples following the manufacturer's instructions. DNA was eliminated by using RNase-Free DNase Set (Qiagen). In brief, $40 \mu \mathrm{l}$ of total RNA was incubated for $10 \mathrm{~min}$ at RT with 2.5 $\mu 1$ DNase I stock solution, $10 \mu \mathrm{l}$ RD buffer in a total volume of $100 \mu \mathrm{l}$. RNA purification and concentration were performed with RNeasy MinElute Cleanup kit (Qiagen) and solubilized in $30 \mu \mathrm{l}$ molecular-grade water. The quantity of quality RNA was determined by measuring the absorbance at 260 and $280 \mathrm{~nm}$ using a NanoDrop 1000 spectrophotometer (Thermoscientific, Wilmington, DE 19810, USA). RNA integrity was verified by gel electrophoresis.

The same procedures were used for a mixture of the following synthetic peptides (GLDIQKVAGT, ELNVPGEIVES, DVENLHLPLPL, GVSKVKEAMAPKH, SSSEESITRIN) (Synpeptide) at a concentration of $0.2 \mathrm{mg} / \mathrm{ml}$ for each peptide.

\section{Reverse Transcription}

The purified RNA was used for reverse transcription by using high-capacity cDNA reverse transcription kit (Applied Biosystems, Burlington, ON, Canada). RNA ( $1 \mu \mathrm{g})$ was mixed with $2 \mu$ l of $10 \times \mathrm{RT}$ buffer, $2 \mu \mathrm{l}$ of $10 \times$ random hexamer primers, $0.8 \mu \mathrm{l}$ of $25 \times \mathrm{dNTP}(100 \mathrm{mM}), 1 \mu \mathrm{l}$ of Multiscribe reverse transcriptase $(50 \mathrm{U} / \mathrm{ml})$ in a total volume of $20 \mu \mathrm{l}$.
A no reverse transcription control was included to confirm the absence of contaminating DNA. The synthesis of cDNA was conducted using a Mastercycler Gradient Thermocycler (Eppendorf, Mississauga, ON, Canada) under the following settings: $25^{\circ} \mathrm{C}$ for $10 \mathrm{~min}, 37^{\circ} \mathrm{C}$ for $120 \mathrm{~min}, 85^{\circ} \mathrm{C}$ for $5 \mathrm{~min}$ and a holding step at $4^{\circ} \mathrm{C}$. The cDNA was stored at $-20^{\circ} \mathrm{C}$ until use.

\section{RT-qPCR}

A ViiA ${ }^{\mathrm{TM}} 7$ Real-Time PCR System (Applied Biosystems, Burlington, ON, Canada) and PowerUp ${ }^{\mathrm{TM}} \mathrm{SYBR}^{\mathrm{TM}}$ Green Master Mix (Applied Biosystems) were used for RT-qPCR. The primers (Table 1) were synthesized by Eurofins Genomics (Huntsville, USA). The primer efficiency was calculated as described before (23) with the formula: $E=10^{(-1 / \text { slope })}$. The PCR was performed in a total volume of $20 \mu \mathrm{l} ; 10 \mu \mathrm{l}$ of PowerUp ${ }^{\mathrm{TM}} \mathrm{SYBR}^{\mathrm{TM}}$ Green Master Mix, $1.6 \mu \mathrm{l}$ of forward primer $(5 \mu \mathrm{M}), 1.6 \mu \mathrm{l}$ of reverse primer $(5 \mu \mathrm{M}), 5 \mu \mathrm{l}$ of $1 / 10$ diluted cDNA and $1.8 \mu \mathrm{l}$ of molecular-grade water with the final primer concentration of $400 \mathrm{nM}$ for all the genes except $16 \mathrm{~S}$ (ribosomal RNA gene) and $r p o D$ (sigma factor). For these two genes, a final primer concentration of $200 \mathrm{nM}$ was used with reaction mixture, $10 \mu \mathrm{l}$ of SYBR ${ }^{\circledR}$ Select Master Mix, $0.8 \mu$ l of forward primer $(5 \mu \mathrm{M})$, $0.8 \mu \mathrm{l}$ of reverse primer $(5 \mu \mathrm{M}), 5 \mu \mathrm{l}$ of $1 / 10$ diluted $\mathrm{cDNA}$ and $3.4 \mu \mathrm{l}$ of molecular-grade water. Each PCR was performed in triplicate in the 96 well plates (MicroAmp ${ }^{\mathrm{TM}}$ Optical 96-Well Reaction Plate with Barcode, Fisher Scientific, Canada). PCR conditions were as follows: UDG activation at $50^{\circ} \mathrm{C}$ for $2 \mathrm{~min}$ and Dual-Lock ${ }^{\mathrm{TM}} \mathrm{DNA}$ polymerase activation at $95^{\circ} \mathrm{C}$ for $2 \mathrm{~min}$, followed by 40 repeated cycles of denaturation, annealing and amplification, at $95^{\circ} \mathrm{C}$ for $15 \mathrm{~s}, 54^{\circ} \mathrm{C}$ for $30 \mathrm{~s}$ and $72^{\circ} \mathrm{C}$ for $45 \mathrm{~s}$. Subsequently, a default dissociation curve $\left(95^{\circ} \mathrm{C}\right.$ for $15 \mathrm{~s}, 60^{\circ} \mathrm{C}$ for $1 \mathrm{~min}$ and $95^{\circ} \mathrm{C}$ for $15 \mathrm{~s}$ ) was performed in the instrument and specific amplicon was verified by a single melting-temperature peak. The transcript levels were normalized to the geometric average of expression for all housekeeping genes for each sample (24). The relative changes in gene expression were calculated by using the formula: $\mathrm{dCT}=\mathrm{CT}$ (target)-CT (Normalizer), then ddCT is calculated by subtracting the $\mathrm{dCT}$ of the untreated sample from the treated one: $\mathrm{ddCT}=\mathrm{dCT}$ (treated)- $\mathrm{dCT}$ (untreated). The relative gene expression is calculated as, $2^{-\mathrm{ddCT}}$. Finally, a fold change was calculated as $-1 / 2^{-\mathrm{ddCt}}(25)$.

\section{Genome Sequencing of $L$. helveticus LH-2 and $L$. acidophilus LA-5}

Genomic DNA was extracted from L. helveticus LH-2 and L. acidophilus La-5 by using the UltraClean Microbial DNA Isolation Kit (Mo-Bio Laboratories, Inc., Canada) according to

TABLE 1 | Oligonucleotides used in this study.

\begin{tabular}{|c|c|c|c|}
\hline Gene & Function & Primer sequences & References \\
\hline hilA & Transcriptional regulator of SPI-1 & F: 5'-TGTCGGAAGATAAAGAGCAT-3'R: 5'-AAGGAAGTATCGCCAATGTA-3' & (19) \\
\hline ssrB2 & Transcriptional regulator of SPI-2 & F: 5'-TGGTTTACACAGCATACCAA-3'R: 5'-GGTCAATGTAACGCTTGTा-3' & $(19)$ \\
\hline $16 S$ & $16 S$ rRNA gene, used as housekeeping gene & F: 5'-CAAGTCATCATGGCCCTTAC-3'R: 5'-CGGACTACGACGCACTITAT-3' & (20) \\
\hline $\operatorname{rop} D$ & Sigma factor, used as housekeeping gene & F: 5'-GTGAAATGGGCACTGTTGAACTG-3'R: 5' -TTCCAGCAGATAGGTAATGGCTTC-3' & $(21)$ \\
\hline gmk & Guanylate kinase, used as housekeeping gene & F: 5'-TTGGCAGGGAGGCGTT-3'R: 5'-GCGCGAAGTGCCGTAGTA AT-3' & $(22)$ \\
\hline
\end{tabular}


the manufacturer's instructions. DNA was eluted in $10 \mathrm{mM}$ Tris$\mathrm{HCl}(\mathrm{pH} \mathrm{8.0)}$. The concentration and the purity of the purified DNA was measured at 260 and $280 \mathrm{~nm}$ using a Nanodrop 1000 spectrophotometer. The integrity of the DNA was verified by agarose (1\%) gel electrophoresis. Extracted DNA samples were stored at $-20^{\circ} \mathrm{C}$. Library preparation and sequencing were performed at the Plateforme d'Analyses Génomiques of the Institut de Biologie Intégrative et des Systèmes (IBIS, Université Laval Quebec, Canada). In short, the libraries were prepared using $500 \mathrm{ng}$ of mechanically fragmented DNA by a Covaris M220 (Covaris) using the NEBNext Ultra II kit (New England Biolabs). TruSeq HT adapters (Illumina) were ligated instead of NEBNext adaptors. The libraries were checked for quality using Bioanalyzer and quantified with Picogreen. The libraries were sequenced on a fraction of a MiSeq run (v3 600 cycles, Illumina) following the manufacturer's instructions. De novo assembly of the reads was performed using CLC Bio Genomic Workbench version 10.1 (Qiagen Inc., Mississauga, ON, Canada) at the Genomics Facility of the Advanced Analysis Centre, University of Guelph. Both the assembled reads and the de novo assembled contigs were BLAST searched (https://blast.ncbi.nlm.nih.gov/ Blast.cgi). Comparative genomic analysis of the proteolytic system was conducted using other related strains $L$. helveticus CNRZ 32 (abbreviation LAC LHE, accession number CP002081) for L. helveticus LH-2 and L. acidophilus NCFM (abbreviation LAC, accession number CP000033) for L. acidophilus La5 using the NCBI microbial genome database and Blast alignment tools.

\section{Measurement of the Cell Envelope Proteinase (CEP) Activities}

L. helveticus LH-2 and L. acidophilus La-5 were grown anaerobically in WPI-sugar based medium supplemented with $10 \mathrm{mM} \mathrm{CaCl}_{2} \cdot 2 \mathrm{H}_{2} \mathrm{O}$ at $37^{\circ} \mathrm{C}$ for $24 \mathrm{~h}$. The cells were harvested by centrifugation at $15,000 \times \mathrm{g}$ for $10 \mathrm{~min}$ at $4^{\circ} \mathrm{C}$ and washed twice with $10 \mathrm{mM} \mathrm{CaCl}_{2}$-saline solution. The supernatant designated as extracellular extract (EE) was used for the measurement of cell lysis rate while the cells were re-suspended in Tris buffer $(50 \mathrm{mM}$, $\mathrm{pH} 7.8)$ to an optical density at $600 \mathrm{~nm}\left(\mathrm{OD}_{600}\right)$ of approximately 10 and were used for CEP and aminopeptidase enzyme assays.

The CEP activity assay of intact cells was performed using the chromogenic substrate N-succinyl-Ala-Ala-Pro-Phep-nitroanilide (Sigma, Markham, ON, Canada) as described previously (26). The reaction mixture was consisted of $200 \mu \mathrm{l}$ resuspended cells, $287.5 \mu \mathrm{l}$ phosphate buffer (0.2 M, pH 7.0), $225 \mu \mathrm{l} 5 \mathrm{M} \mathrm{NaCl}$ and $37.5 \mu \mathrm{l} \mathrm{N}$-succinyl-Ala-Ala-Pro-Phe-pnitroanilide $(20 \mathrm{mM})$. The reaction components were mixed gently and incubated at different temperatures $(35,40,45,50$, and $55^{\circ} \mathrm{C}$ ) for $30 \mathrm{~min}$ to determine the effect of temperature on the proteinase activity. The reactions were stopped by adding $175 \mu \mathrm{l}$ of $80 \%(\mathrm{v} / \mathrm{v})$ acetic acid followed by centrifugation at $13,000 \times \mathrm{g}$ for $5 \mathrm{~min}$. The release of p-nitroanilide (pNA) was measured at $410 \mathrm{~nm}$ using Beckman DU 500-Spectrophotometer. The enzyme activity was calculated using a molar absorption coefficient $(\varepsilon)$ of $8,800 \mathrm{~mol}^{-1} \mathrm{~cm}^{-1}$. One unit of protease activity was defined as $1 \mathrm{nmol}$ of $\mathrm{p}$-nitroanilide released per minute. The specific protease activity was calculated as one unit of protease from $1 \mathrm{mg}$ of cell protein. The protein content was estimated using the method of Bradford (27). Bovine serum albumin (Thermoscientific, Rockford, USA) was used as a standard to measure the protein content.

\section{Aminopeptidase Activities}

Suspensions of harvested cells with $\mathrm{OD}_{600}$ of approximately 10 were used for preparation of intracellular extracts (IE) according to Pescuma et al. (28), cells were disrupted by using Microbead tubes (Mo-Bio Laboratories, Inc., Canada) in a microbead tube vortex for $6 \mathrm{~min}$ at maximum speed with 1 min interruption on ice after each minute. Beads, cell debris and unbroken cells were removed by centrifugation $\left(10,000 \times g\right.$ at $4^{\circ} \mathrm{C}$ for $\left.5 \mathrm{~min}\right)$ and the supernatant fluid was designated as the intracellular enzymatic extract (IE) which was maintained on ice and immediately used for enzymatic assays. Intracellular aminopeptidase activity was assayed with the chromogenic substrate Lys- $\rho \mathrm{Na}$ (Sigma) as previously described (29) by incubation of $100 \mu$ l of IE with $400 \mu \mathrm{l}$ of Tris- $\mathrm{HCl}$ buffer $(50 \mathrm{mM}, \mathrm{pH} 7.0)$ and $50 \mu \mathrm{l}$ Lys- $\rho \mathrm{Na}$ $(10 \mathrm{mM})$ at five temperatures $\left(35,40,45,50\right.$, and $\left.55^{\circ} \mathrm{C}\right)$ for $20 \mathrm{~min}$ to determine the effect of temperature on the aminopeptidase activity. The reaction was stopped by addition of $1 \mathrm{~mL}$ of $30 \%$ acetic acid. The concentration of $\rho$-nitroanilide released was quantified at $410 \mathrm{~nm}$. Enzyme activities were calculated by using a molar absorbance coefficient of $9,024 \mathrm{~mol}^{-1} \mathrm{~cm}^{-1}$ under the assay conditions. One unit of enzyme activity was defined as the amount of enzyme required to release $1 \mathrm{nmol}$ of $\rho$-nitroanilide per min under the assay conditions. The specific peptidase activity was calculated as one unit of peptidase from $1 \mathrm{mg}$ of cell protein. Aminopeptidase activity was measured in EE by the same procedures to detect rate of cell lysis.

\section{Identification of Peptides Through Liquid Chromatography-Mass Spectrometry Analysis (LC-MS)}

Filtered CFSM was fractionated at three successive cut-off protein concentrator sizes 100,50 , and $3 \mathrm{kDa}$, respectively, using GE Healthcare Vivaspin ${ }^{\mathrm{TM}} 20$ protein concentrator (Fisher Scientific). The filtrate was freeze dried for $72 \mathrm{~h}$. A control sample of filter sterilized WPI CFSM was included. The freeze-dried filtrate of $30 \mathrm{ml}$ CFSM was reconstituted in $300 \mu \mathrm{l}$ Milli-Q water and peptides were identified on an Agilent 1200 HPLC liquid chromatograph interfaced with an Agilent UHD 6530 Q-Tof mass spectrometer at the Mass Spectrometry Facility of the Advanced Analysis Centre, University of Guelph (30). Briefly, a C18 column (Agilent Advance Bio Peptide Map, 100 $\times 2.1 \mathrm{~mm} 2.7 \mu \mathrm{m}$ ) was used for chromatographic separation with the following solvents, water with $0.1 \%$ formic acid for $\mathrm{A}$ and acetonitrile with $0.1 \%$ formic acid for B. The mobile phase gradient was $2 \% \mathrm{~B}$ increasing to $45 \% \mathrm{~B}$ in $40 \mathrm{~min}$ and then to $55 \%$ B in 10 more minutes followed by column wash at $95 \%$ B and 10 -min re-equilibration with a flow rate $0.2 \mathrm{~mL} / \mathrm{min}$.

The mass spectrometer electrospray capillary voltage was maintained at $4.0 \mathrm{kV}$ and the drying gas temperature at $350^{\circ} \mathrm{C}$ with a flow rate of $13 \mathrm{~L} / \mathrm{min}$. Nebulizer pressure was $40 \mathrm{psi}$ 
and the fragmentor was set to 150 . Nitrogen was used as both nebulizing and drying gas, and collision-induced gas. The mass-to-charge ratio was scanned across the $\mathrm{m} / \mathrm{z}$ range of $300-2,000 \mathrm{~m} / \mathrm{z}$ in $4 \mathrm{GHz}$ extended dynamic range positiveion auto MS/MS mode. Three precursor ions per cycle were selected for fragmentation. The sample injection volume was $20 \mu$ l. Raw data files were loaded directly into PEAKS 8 software (Bioinformatics Solutions Inc.) and subjected to de novo sequencing with SwissProt database searching. The tolerance values used were $15 \mathrm{ppm}$ for parent ions and $0.05 \mathrm{Da}$ for fragment ions. See Supplementary Table S1 for information used to identify peptides.

\section{Statistical Analysis}

All experiments were carried out three independent times with triplicates of each sample. Means and standard deviations were analyzed using ANOVA followed by Tukey's post hoc test with a $P$-value of $\leq 0.05$ considered significant.

\section{RESULTS}

\section{Activity of $L$. helveticus $\mathrm{LH}-2$ and $L$. acidophilus La-5 CFSM on Bioluminescent Reporter Strains}

Bioluminescent reporter strains S. Typhimurium hilA::lux and $s s r B:: l u x$ were used for initial screening of the antivirulence effects of CFSM obtained from WPI fermented with L. helveticus LH2 and $L$. acidophilus La-5. CFSM from both strains reduced luminescence of the S. Typhimurium hilA::lux while only La5 could decrease ssrB::lux reporter luminescence; indicating down-regulation of the hilA and $s s r B$ genes (Figures 1A,B). Both uninoculated control WPI had no downregulatory effect on S. Typhimurium hilA::lux light emission with a slight but significant increase in expression of the same gene in WPI glucose based media (Figure 1A). The uninoculated WPI sucrose based medium had no effect on $S$. Typhimurium ssrB::lux luminescence while WPI glucose based media showed significant down regulation of $S$. Typhimurium ssrB::lux luminescence (Figure 1B).

Bioluminescent reporter genes are considered a rapid tool for initial monitoring of gene expression. However, bioluminescence may be influenced by several factors, including other components of the medium. Previous observations using luminescent constructs suggest the occurrence of false positives and negatives with respect to virulence gene expression $(12,19,31,32)$. This is why an alternative method was chosen to complement the bioluminescence assay results. RT-qPCR is a highly sensitive and specific method for gene expression analysis.

\section{Effect of L. helveticus LH-2, L. acidophilus La-5 Bioactive Molecules and Mixture of Synthetic Peptides on Virulence Genes in S. Typhimurium DT 104 Wild Type and S. Typhimurium oppA Mutant Strains}

The effects of the neutralized and reconstituted CFSM from L. helveticus LH-2 and L. acidophilus La-5 on virulence gene expression in multi-drug resistant $S$. Typhimurium DT104 and $S$. Typhimurium oppA mutant were analyzed by a 2-step RT qPCR method after incubation for $3 \mathrm{~h}$ (Figure 2). A statistically significant down-regulation of both the hilA and $s s r B$ genes of S. Typhimurium DT 104 was observed after incubation with $10 \%$ CFSM from both LH-2 and La-5. La-5 CFSM showed stronger repression of S. Typhimurium DT104 hilA and ssrB
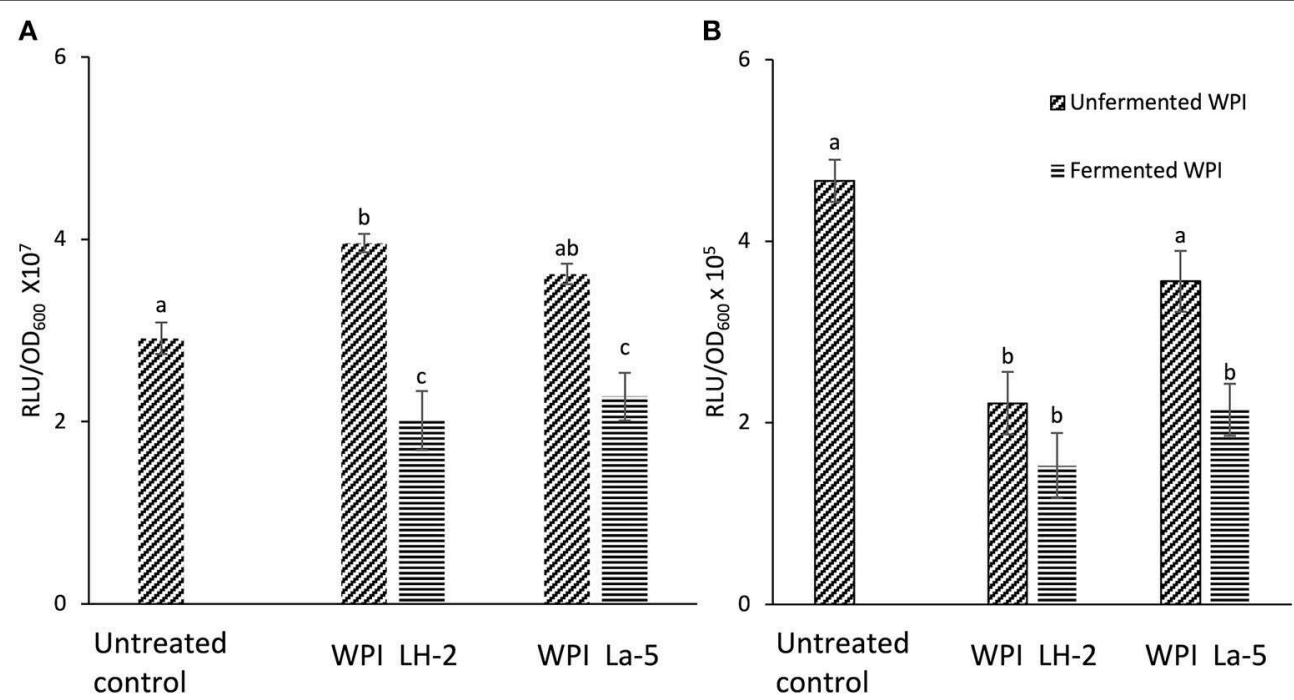

FIGURE 1 | Bioluminescence of S. Typhimurium hilA::/ux (A) and ssrB::/ux (B) measured after 3 h of incubation in LB broth alone (Untreated control), LB broth supplemented with 10\% non-fermented WPI-sugar CFSM (Unfermented WPI) and LB broth supplemented with $10 \%$ L. helveticus LH-2 or L. acidophilus La-5 CFSM (Fermented WPI). Data are the means \pm the standard deviations derived from triplicate assays and statistical analysis was carried out using ANOVA followed by Tukey's post hoc test. Different letters indicate significant differences $(P$-value of $\leq 0.05)$ within each subsection of the figure. 


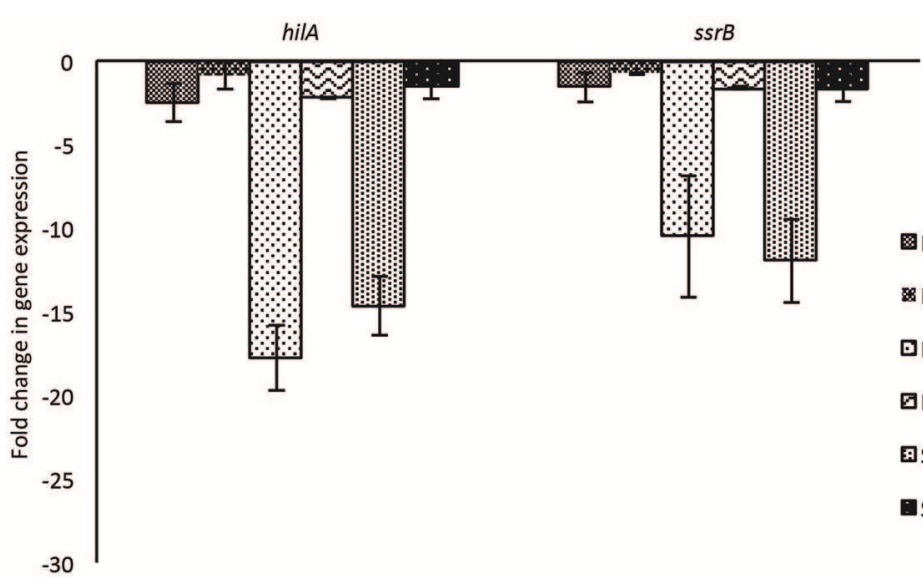

잔 2 CFSM+S. Typhimurium DT104

LH-2 CFSM+S. Typhimurium oppA mutant

口La-5 CFSM+S. Typhimurium DT104

- La-5CFSM+S. Typhimurium oppA mutant

ĐSynthetic peptide mixture+S. Typhimurium DT104

Synthetic peptide mixture+S. Typhimurium oppA mutant

FIGURE 2 | Effect of L. helveticus LH-2 and L. acidophilus La-5 CFSM on virulence gene expression of S. Typhimurium DT104 and S. Typhimurium oppA mutant. Expression ratios of hilA and ssrB genes of $S$. Typhimurium were normalized to the expression of the geometric average of regulator genes $16 S$ rRNA, rpoD, gmk to obtain the fold-change and compared with those of the non-fermented media.

genes $(-17.8$ and -10.49 , respectively) than LH-2 CFSM $(-2.56$ and -1.58 , respectively). The expression of hilA and $s s r B$ genes in $S$. Typhimurium $o p p A$ mutant strain was -2.23 and -1.61 , respectively, in the presence of La-5 CFSM while in the presence of LH-2 CFSM, expression of both genes was -0.92 and -0.77 , respectively (Table 2 ).

The synthetic peptides mixture could also downregulate the expression of hilA and ssrB genes in S. Typhimurium DT104 ( -14.66 and -11.99 , respectively). The relative expression of the same genes in the $S$. Typhimurium oppA mutant strain in the presence of the same peptide mixture was -1.60 and -1.67 , respectively (Figure 2 ).

\section{Genes Associated With Oligopeptide Metabolism in $L$. helveticus LH-2 and $L$. acidophilus LA-5}

L. helveticus CNRZ 32 and L. acidophilus NCFM have previously sequenced complete genomes with the most thoroughly characterized proteolytic system $(15,33)$. Whole Genome Sequencing (WGS) and comparative analysis of the proteolytic components of L. helveticus LH-2 and L. acidophilus La-5 with L. helveticus CNRZ 32 and L. acidophilus NCFM, respectively, show some genetic differences in the distribution of proteolytic elements in LH-2 and La-5 (Tables 3, 4). The L. helveticus LH-2 genome codes for prtH3, prtH4, and prtM2 CEP genes (99, 99, and $100 \%$ nucleotide identity, respectively) with the absence of prtH, prtH2 and prtM genes (Table 3). The L. acidophilus La-5 genome codes for prtP and prtM CEP genes $(99,100 \%$ identity, respectively) (Table 4 ).

Comparative genome analysis of L. helveticus LH-2 for oligopeptide transport elements and peptidases shows the presence of these proteolytic components with high identity (97-100\%) (Table 3). The L. acidophilus La-5 genome codes for oligopeptide transport elements and peptidases of L. acidophilus NCFM with high identity (99-100\%), except for oppB2 $(33 \%$ identity) (Table 4).

\section{CEP Activities of $L$. helveticus LH-2 and $L$. acidophilus LA-5 in WPI}

The CEP activities of intact cells from the medium fermented by L. helveticus LH-2 and L. acidophilus La-5 were measured based on the in vitro hydrolysis of the chromogenic substrate N-succinyl-Ala-Ala-Pro-Phe-p-nitroanilide. The optimal temperature for the proteinase activity of LH-2 strain was $45^{\circ} \mathrm{C}$ with enzyme activity 3.60 while the maximum CEP activity of La-5 was $0.25 \pm 0.01$ at $40^{\circ} \mathrm{C}$ (Table 5).

\section{Intracellular Aminopeptidase Activities of L. helveticus LH-2 and L. acidophilus LA-5 in WPI}

For LH-2 intracellular extract, the highest aminopeptidase activity was $22.06 \pm 0.60$ at $40^{\circ} \mathrm{C}$ while La-5 optimal activity of aminopeptidase was $5.19 \pm 0.55$ at $35^{\circ} \mathrm{C}$ (Table 5). Negligible peptidase activity was detected in the extracellular supernatant using Lys-pNa, indicating that peptidase release from the cells during our experiments was below the detection limit (data not shown).

\section{Peptide Profiling of CSFM of Unfermented WPI and WPI Fermented With $L$. helveticus LH-2 and $L$. acidophilus LA-5 Strains}

Liquid chromatography-mass spectrometry (LC-MS) analysis of unfermented WPI and WPI fermented with LH-2 and La5 showed that peptides are almost all fragments of the main milk proteins $(109,75$, and 15 milk protein derived peptides, respectively) (Figure 3). Out of these, 56 peptides were unique to the $3-\mathrm{kDa}$ fraction from $\mathrm{LH}-2$ fermented medium while 9 were unique to La-5 fermented medium. CEP cleavage sites are not evenly distributed throughout the protein sequences. Regions of highest proteolytic activity are demonstrated by heat maps of peptides (Figure 4). Thus, the presence of hot spots of cleavage sites are represented by changes in color scale, where 


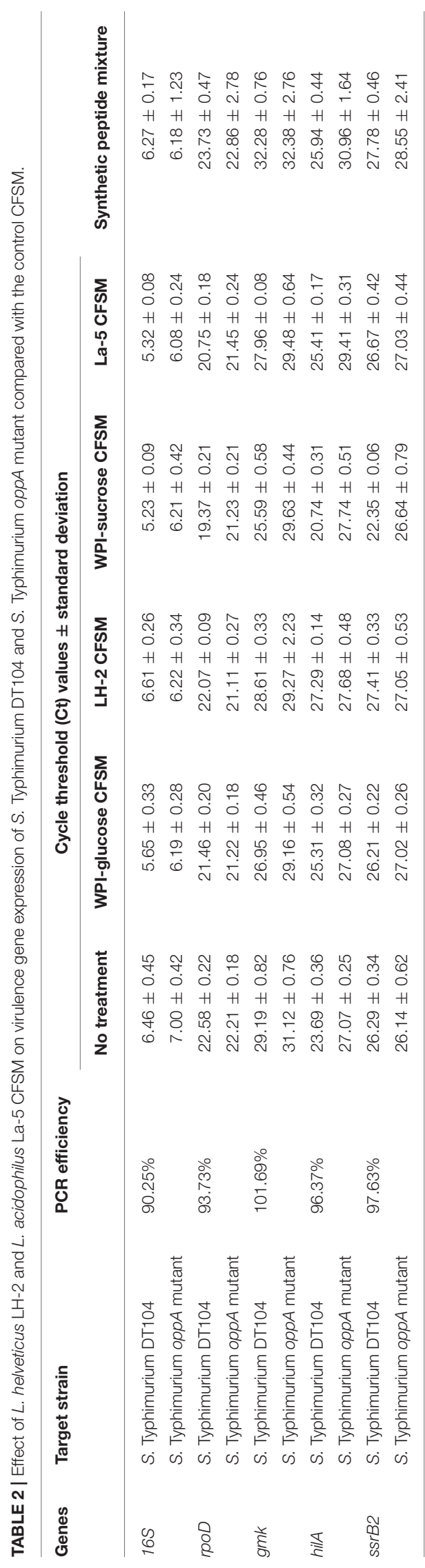

TABLE 3 | Comparative genome analysis of the proteolytic system of $L$. helveticus LH-2 with L. helveticus CNRZ 32 (abbreviation LAC LHE, accession number CP002081) at the nucleotide level using NCBI microbial genome database and Blast alignment tools.

Gene (NCBI accession number) Identity (\%)

\section{CELL ENVELOPE-ASSOCIATED PROTEINASES}

prtH (AAD50643)

prtH2 (DQ826130)

prtH3 (HQ602769)

prtH4 (HQ602770)

prtM (DQ826131)

prtM2 (DQ826132)

\section{OLIGOPEPTIDE TRANSPORT}

oligopeptide $A B C$ transport protein ATP-binding component OppF2 (AGQ24255.1)

oligopeptide ABC transport protein ATP-binding component OppD2 (AGQ24256.1)

oligopeptide ABC transport protein ATP-binding component OppF1 (AGQ23787.1)

oligopeptide $A B C$ transport protein ATP-binding component OppD1 (AGQ23788.1)

oligopeptide $A B C$ transport protein periplasmic component OppA4 (AGQ24260.1)

oligopeptide $A B C$ transport protein periplasmic component OppA5 (AGQ24261.1)

oligopeptide ABC transport protein ATP-binding component OppB2 (AGQ24258.1)

oligopeptide $A B C$ transport protein permease component OppC2 (AGQ24257.1)

oligopeptide $A B C$ transport protein permease component OppC1 (AGQ23785.1)

\section{PEPTIDASES}

Oligoendopeptidase pepF (AY365129)

Oligoendopeptidase pepO (AF019410)

Oligoendopeptidase pepO2 (DQ826126)

sialoglycoprotein endopeptidase Ogcp (DQ826107)

General aminopeptidases pepCE (JF811429)

General aminopeptidases pepC (HQ602766)

General aminopeptidases pepN (U08224)

X-prolyl diaminopeptidase pepX (U22900)

Proline iminopeptidases pepl (DQ826125)

Proline iminopeptidases pepR (U05214)

Prolidase pepQ (AF012084)

Prolidase pepQ2 (DQ826127)

Dipeptidase pepD (U34257)

Dipeptidase pepD2 (DQ826122)

Dipeptidase pepD3 (DQ826123)

Dipeptidase pepV (AF012085)

Tripeptidase pepT (DQ826128)

Tripeptidase pepT2 (DQ826129)

Glutamyl aminopeptidase pepA (DQ826138)

Methionine aminopeptidase map (DQ826118)

Pyrrolidone carboxyl peptidase pcp (DQ826121)

SprT-like metallopeptidase sprT (HQ602765)

M16 family metallopeptidase hyp prt2 (DQ826112)

Membrane alanine aminopeptidase pepM1 (HQ602768)
$2,363 / 2,370(99 \%)$

2,690/2,691 (99\%)

$1,939 / 1,947(99 \%)$

1,050/1,050 (100\%)

$1,314 / 1,314(100 \%)$

$1,349 / 1,350(99 \%)$

$3,754 / 3,787(99 \%)$

$3,204 / 3,204(100 \%)$

$885 / 885(100 \%)$

$1,259 / 1,260(99 \%)$

$2,177 / 2,181(99 \%)$

$1,110 / 1,110(100 \%)$

$2,244 / 2,253(99 \%)$

$1,422 / 1,422(100 \%)$

$1,424 / 1,428(99 \%)$

$2,402 / 2,404(99 \%)$

$1,242 / 1,242(100 \%)$

$1,287 / 1,287(100 \%)$

$1,083 / 1,083(100 \%)$

$828 / 828(100 \%)$

$603 / 603$ (100\%)

470/471 (99\%)

1,257/1,257 (100\%)

$1,515 / 1,515(100 \%)$ 
TABLE 4 | Comparative genome analysis of the proteolytic system of $L$. acidophilus La-5 with L. acidophilus NCFM (abbreviation LAC, accession code CP000033) at the nucleotide level using NCBI microbial genome database and Blast alignment tools.

\begin{tabular}{|c|c|}
\hline Gene (NCBI accession number) & Identity (\%) \\
\hline \multicolumn{2}{|l|}{ CELL ENVELOPE-ASSOCIATED PROTEINASES } \\
\hline prtP (LBA1512) & $1,626 / 1,627$ (99\%) \\
\hline prtM (LBA1588) & $300 / 300$ (100\%) \\
\hline \multicolumn{2}{|l|}{ Oligopeptides transport: } \\
\hline Oligopeptide binding protein oppA (LBA0197) & $1,626 / 1,626(100 \%)$ \\
\hline $\begin{array}{l}\text { Oligopeptide ABC transporter, binding protein oppA1B } \\
\text { (LBA0198) }\end{array}$ & $542 / 542(100 \%)$ \\
\hline $\begin{array}{l}\text { Oligopeptide ABC transporter, permease protein oppB1 } \\
\text { (LBA0200) }\end{array}$ & $309 / 309$ (100\%) \\
\hline $\begin{array}{l}\text { Oligopeptide ABC transporter, permease protein oppC1 } \\
\text { (LBA0201) }\end{array}$ & $343 / 343(100 \%)$ \\
\hline $\begin{array}{l}\text { Oligopeptide ABC transporter, ATP binding protein } \\
\text { oppD1 (LBA0202) }\end{array}$ & $352 / 352(100 \%)$ \\
\hline $\begin{array}{l}\text { Oligopeptide ABC transporter, ATP binding protein } \\
\text { oppF1 (LBA0203) }\end{array}$ & $313 / 314(99 \%)$ \\
\hline $\begin{array}{l}\text { Oligopeptide ABC transporter, substrate binding protein } \\
\text { oppA3 (LBA1216) }\end{array}$ & $527 / 527(100 \%)$ \\
\hline $\begin{array}{l}\text { Oligopeptide ABC transporter, substrate binding protein } \\
\text { oppA2 (LBA1300) }\end{array}$ & $584 / 585(99 \%)$ \\
\hline $\begin{array}{l}\text { Oligopeptide ABC transporter, substrate binding protein } \\
\text { oppA2B (LBA1301) }\end{array}$ & $589 / 589$ (100\%) \\
\hline $\begin{array}{l}\text { Oligopeptide ABC transporter, permease protein oppC2 } \\
\text { (LBA1302) }\end{array}$ & $309 / 309$ (100\%) \\
\hline $\begin{array}{l}\text { Oligopeptide ABC transporter, permease protein oppB2 } \\
\text { (LBA1303) }\end{array}$ & $105 / 319(33 \%)$ \\
\hline $\begin{array}{l}\text { Oligopeptide ABC transporter, ATP binding protein } \\
\text { oppF2 (LBA1305) }\end{array}$ & $328 / 328(100 \%)$ \\
\hline $\begin{array}{l}\text { Oligopeptide ABC transporter, ATP binding protein } \\
\text { oppD2 (LBA1306) }\end{array}$ & $342 / 343(99 \%)$ \\
\hline $\begin{array}{l}\text { Oligopeptide ABC transporter, substrate binding protein } \\
\text { oppA6 (LBA1400) }\end{array}$ & $581 / 581(100 \%)$ \\
\hline $\begin{array}{l}\text { Oligopeptide ABC transporter, substrate binding protein } \\
\text { oppA9 (LBA1961) }\end{array}$ & $542 / 542(100 \%)$ \\
\hline \multicolumn{2}{|l|}{ PEPTIDASES } \\
\hline Dipeptidase (LBA0035) & $466 / 466$ (100\%) \\
\hline Prolyl aminopeptidase (LBA0092) & 293/293 (100\%) \\
\hline Metallopeptidase pepO (LBA0165) & $649 / 650(99 \%)$ \\
\hline Pyrrolidone carboxyl peptidase (LBA0186) & 200/200 (100\%) \\
\hline Dipeptidase pepG (LBA0195) & $437 / 437$ (100\%) \\
\hline Dipeptidase pepE (LBA0204) & 438/438 (100\%) \\
\hline Prepilin peptidase (LBA0286) & 228/229 (99\%) \\
\hline Aminopeptidase C pepC (LBA0343) & $449 / 449$ (100\%) \\
\hline Endopeptidase (LBA0390) & $348 / 349$ (99\%) \\
\hline Xaa-pro dipeptidase (LBA0430) & $1,117 / 1,117(100 \%)$ \\
\hline ampM Methionine aminopeptidase (LBA0623) & $274 / 275$ (99\%) \\
\hline pepC Aminopeptidase (LBA0911) & $437 / 437$ (100\%) \\
\hline pepD Metallopeptidase (LBA0994) & $467 / 467$ (100\%) \\
\hline Signal peptidase (LBA1182) & 256/257 (99\%) \\
\hline pepT Tripeptide aminopeptidase (LBA1190) & $427 / 427$ (100\%) \\
\hline pepO Metallopeptidase (LBA1275) & $649 / 650$ (99\%) \\
\hline pepP Xaa-Pro aminopeptidase (LBA1336) & $1,124 / 1,124(100 \%)$ \\
\hline
\end{tabular}

(Continued)
TABLE $4 \mid$ Continued

\begin{tabular}{lc}
\hline Gene (NCBI accession number) & Identity (\%) \\
\hline pepQ Metallopeptidase (LBA1343) & $596 / 596(100 \%)$ \\
pepX X-prolyl dipeptidyl aminopeptidase (LBA1373) & $793 / 793(100 \%)$ \\
pepT Tripeptide aminopeptidase (LBA1515) & $427 / 427(100 \%)$ \\
vanY d-alanyl-d-alanine carboxypeptidase (LBA1603) & $1,312 / 1,312(100 \%)$ \\
Prolyl aminopeptidase (LBA1658) & $928 / 928(100 \%)$ \\
pepF Oligoendopeptidase (LBA1763) & $598 / 598(100 \%)$ \\
pepN Membrane alanyl aminopeptidase (LBA1849) & $844 / 844(100 \%)$ \\
Signal peptidase (LBA1909) & $210 / 210(100 \%)$ \\
pepL Leucyl aminopeptidase (LBA1957) & $299 / 299(100 \%)$ \\
\hline
\end{tabular}

red represents more numerous peptides. The undigested WPI shows many plasmin and cathepsin cleavage sites (Figures 58). Endogenous milk peptides were mostly not found after fermentation with LH-2 and La-5 strains, except 14 peptides from $\beta$-casein and one peptide from $\alpha_{s 2}$-casein (Figure 3). Most peptides found in the supernatant of LH-2 and La-5 fermented media display low-affinity residues for oligopeptide binding proteins (negatively charged amino acids, peptides with glycine, proline and glutamine at position 4,5 , or 6 , peptides with proline at second position, VPP and IPP containing peptides and phosphorylated peptides) and higher resistance to peptidase hydrolysis (Figures 5-9).

Identification of bioactive peptide sequences was conducted through a search of the peptide literature databases (Table 6). Out of the 109 peptides in undigested WPI, 39 peptides have previously reported bioactivity (antihypertensive, antimicrobial, antioxidative, immunomodulatory, antithrombotic, opioid and antidiabetic activity). A total of 75 peptides were found in $L$. helveticus LH-2 CFSM, 19 of these peptides have previously been associated with several categories of bioactivity (ACEinhibitory, opioid, antimicrobial and antioxidant activities). For L. acidophilus La-5 CFSM, a total of 15 peptides were sequenced, 5 of these peptides have previously been reported with ACEinhibitory, antioxidant, antimicrobial and anti-caries activities. Some of these peptides have multifunctional properties that can modulate two or more physiological processes (Table 6).

\section{DISCUSSION}

Several previous studies showed the ability of lactic acid bacteria to down regulate the expression of virulence genes of enteropathogenic bacteria $(31,86,87)$. In this study, CFSM collected from WPI fermented by L. helveticus LH-2 and $L$. acidophilus La-5 reduced the expression of both the hilA and $s s r B$ genes of the S. Typhimurium DT 104 wild strain. L. acidophilus La-5 has the most significant down-regulatory effect on the virulence genes, which indicates that the antivirulence effect is strain dependent and affected by the nature and components of CFSM. WPI fermented by La- 5 contains 9 unique peptides not found in LH-2-fermented or unfermented medium.

Delcenserie et al. (32) reported that glucose could up or down-regulate the expression of virulence genes in E. coli 
TABLE 5 | Specific proteinase and aminopeptidase activities of intact cells and intracellular enzymatic extract of $L$. helveticus LH-2 and L. acidophilus La-5 after growth anaerobically in WPI-sugar based media at $37^{\circ} \mathrm{C}$ for $24 \mathrm{~h}$.

\begin{tabular}{|c|c|c|c|c|}
\hline \multirow{2}{*}{$\begin{array}{l}\text { Temperature } \\
\left({ }^{\circ} \mathrm{C}\right)\end{array}$} & \multicolumn{2}{|c|}{ Specific proteinase activity } & \multicolumn{2}{|c|}{ Specific aminopeptidase activity } \\
\hline & L. helveticus LH-2 & L. acidophilus La-5 & L. helveticus LH-2 & L. acidophilus La-5 \\
\hline 35 & $1.66 \pm 0.04$ & $0.05 \pm n d$ & $19.74 \pm 0.27$ & $5.19 \pm 0.55$ \\
\hline 40 & $2.12 \pm 0.11$ & $0.25 \pm 0.01$ & $22.06 \pm 0.60$ & $4.08 \pm 0.74$ \\
\hline 45 & $3.60 \pm n d$ & $0.14 \pm 0.01$ & $7.82 \pm 0.91$ & $4.43 \pm 0.37$ \\
\hline 50 & $3.44 \pm 0.03$ & $0.21 \pm 0.01$ & $3.41 \pm 0.23$ & $2.15 \pm 0.72$ \\
\hline 55 & $3.01 \pm 0.03$ & $0.06 \pm 0.01$ & $14.78 \pm 1.32$ & $2.75 \pm 0.36$ \\
\hline
\end{tabular}

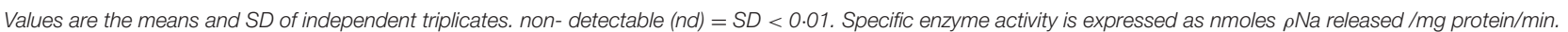

O157:H7. In our study, glucose and sucrose may also affect virulence gene expression in $S$. Typhimurium. A peptidic fraction, isolated from milk fermented with $L$. helveticus, downregulated $s s r B$ gene expression of $S$. Typhimurium in the absence of glucose in the growth medium (10). CFSM from MRS without glucose fermented with some bifidobacteria species showed down-regulation of genes hilA, ssrB2, and sopD (88). These studies suggest that down-regulation of virulence genes could be caused by other non-carbohydrate metabolites produced after fermentation.

Absence of the downregulatory effect of L. helveticus LH2 and L. acidophilus La-5 CFSM on the Salmonella oppA mutant strain signifies the importance of peptide transport inside $S$. Typhimurium to inhibit virulence gene expression. Regulation of virulence gene expression requires sensing of a specific signal in the environment such as autoinducers for quorum sensing (QS) and these signals affect the growth, metabolism and virulence of bacteria (89). Exogenous leucine increases the transport of peptides by the Opp system and enhances OppA synthesis (90). Also, activity of Opp increases the intracellular amino acid pool, which in turn activates global regulators such as Lrp or CodY (91). Baek et al. (92) reported that Lrp responds to the nutritional environment and has a repressor function on key virulence regulator genes of $S$. enterica Serovar Typhimurium by strong interaction with hilA and other SPI-1 and SPI-2 genes, affecting their expression by binding directly to their promoter regions $\mathrm{P}_{h i l A}, \mathrm{P}_{\text {invF }}$ and $\mathrm{P}_{s s r A}$. From these studies and our data, it can be concluded that the presence of the $S$. Typhimurium oppA gene is a key factor in sensing oligopeptides, which can act as a specific signal for down regulation of virulence genes once transported into the cell.

The downregulatory effect of the synthetic peptide mixture demonstrates the antivirulence effect of specific peptides produced by L. helveticus LH-2 and L. acidophilus La-5 CFSM on the $S$. Typhimurium virulence genes. Also, the absence of this downregulatory effect for the $S$. Typhimurium oppA mutant strain shows the importance of internalization of such peptides inside $S$. Typhimurium to exhibit the antivirulence effect.

Presence of more than one CEP paralog is common among L. helveticus strains (93). Also, the presence of prtH3 and prtH4 with the absence of prtH in L. helveticus LH-2 is not unusual as prtH is not broadly distributed within L. helveticus and has no effect on growth rate in milk and cheese whey (94). prtH and prtH2 distribution is also strain dependent (95). The prtH3/prtH4 combination is common in L. helveticus strains (96). These studies agree with our findings for the presence of prtH3 and prtH4 genes and absence of prtH and prtH2 genes in the genome of the LH-2 strain. PrtM is required for activation of PrtH and PrtM2 plays a role in activation of other CEP paralogs in $L$. helveticus (97). Thus, absence of PrtM in LH-2 is expected as this gene was almost exclusively restricted to strains that also contained prtH (33).

Presence of both PrtP (proteinase precursor) and PrtM (maturase) in L. acidophilus La-5 confirmed that La-5 can digest large proteins extracellularly and produce small peptides. Genay et al. (95) reported that the genetic biodiversity of CEP paralogs between LAB strains could affect growth rate, strain functionality and bioactive peptide production in dairy products. This could cause differences in the antivirulence activities and bioactive peptides between of LH-2 and La-5 after growth in WPI.

Peptide transport systems can be specific for oligopeptides, or di- and tri-peptides (98). L. helveticus LH-2 contains all oligopeptide $\mathrm{ABC}$ transport elements, which is not different from previous studies of $L$. helveticus strains (99). L. acidophilus La- 5 shows low identity of $o p p B 2$ which is encoded by the opp2-type operon (100). Azcarate-Peril et al. (101) reported that Opp1 and Opp2 might have different specificities, which could explain accumulation of some peptides in La-5 growth media. Doeven et al. (98) also concluded that the lack of some elements of the membrane complex, OppBCDF, leads to presence of some peptides outside the cells due to the specificity of the transport process.

The functionality of these enzymes after genome analysis of $L$. helveticus LH-2 and L. acidophilus La-5 strains was determined by measuring the proteolytic enzyme activities. The optimal temperature for the proteinase activity of $\mathrm{LH}-2\left(45^{\circ} \mathrm{C}\right)$ is not different from other previously reported L. helveticus strains (40$\left.50^{\circ} \mathrm{C}\right)(102-104)$. The maximum CEP activity of La-5 (40 and $50^{\circ} \mathrm{C}$ ) also is not significantly different from other L. acidophilus strains $\left(45-50^{\circ} \mathrm{C}\right)$ previously reported (105).

L. helveticus LH2 CEP activity in WPI was lower than the CEP activity of other L. helveticus strains previously reported in skim milk $(104,106)$. The CEP activity of La-5 was slightly lower than the CEP activity of the same strain in skim milk (106) and significantly lower than the CEP activities of other L. acidophilus 


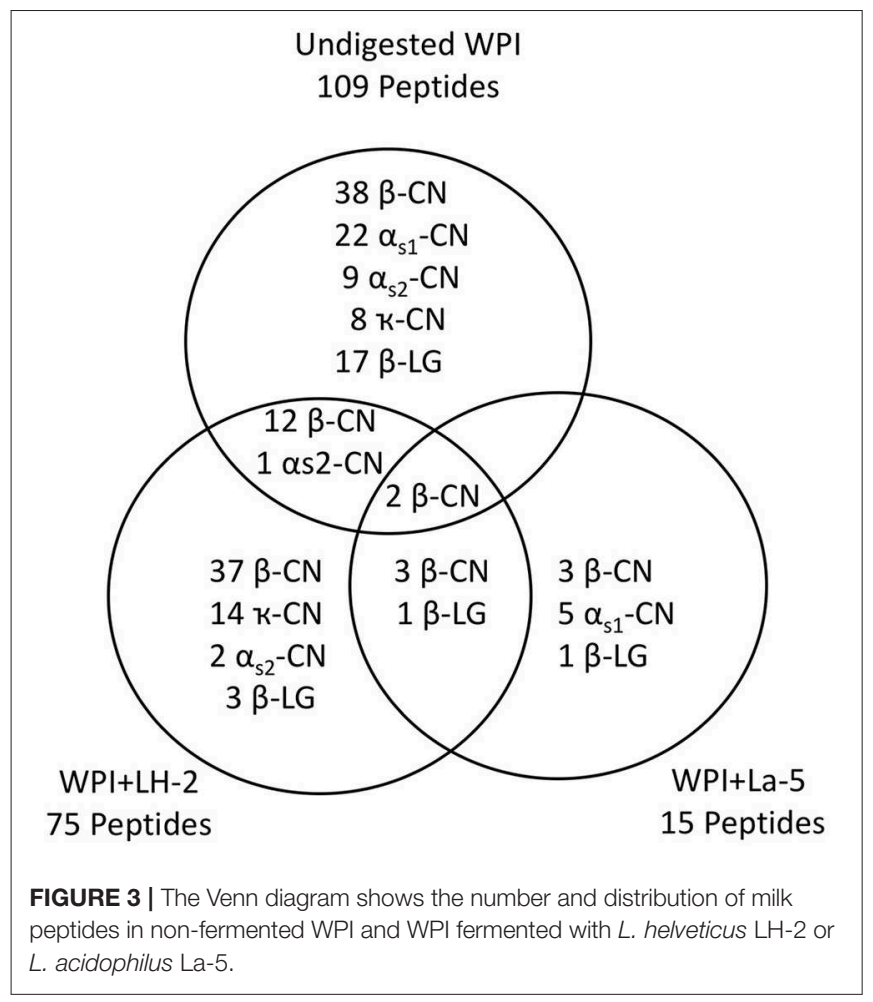

strains in chemically defined medium (107). The presence of peptides in the growth medium could inhibit the proteinase activity of some LAB (108). Mass spectrometry analysis of non-fermented WPI in this study confirmed the presence of endogenous milk protein derived peptides $\left(\beta-, \alpha_{\mathrm{s} 1^{-}}, \alpha_{\mathrm{s} 2^{-}}, \kappa-\right.$ casein, and $\beta$-lactoglobulin) after ultrafiltration of milk during the WPI production process. The presence of these endogenous peptides in the growth media could explain the lower CEP activities of LH-2 and La-5 in WPI compared with other related strains in milk-based growth media. The CEP activity levels of lactobacilli depend on the strain, nature and quantity of peptides present in the growth media (96). The regulation of proteinase activity is also strain dependent (107). These factors suggest that CEP activities of LH- 2 and La- 5 are different in WPI than other milk-based media.

L. helveticus LH-2 aminopeptidase activity in WPI based medium was significantly lower compared with previously studied L. helveticus strains after growth in simplified chemically defined medium (SCDM) supplemented with different nitrogen sources (109). L. acidophilus La-5 had higher aminopeptidase activity compared with $L$. acidophilus strains mentioned in Pescuma et al. (28) when grown in a chemically defined medium (CDM). The aminopeptidase activities are not influenced by the peptide content of the medium (109), so this difference may be mainly strain dependent (110).
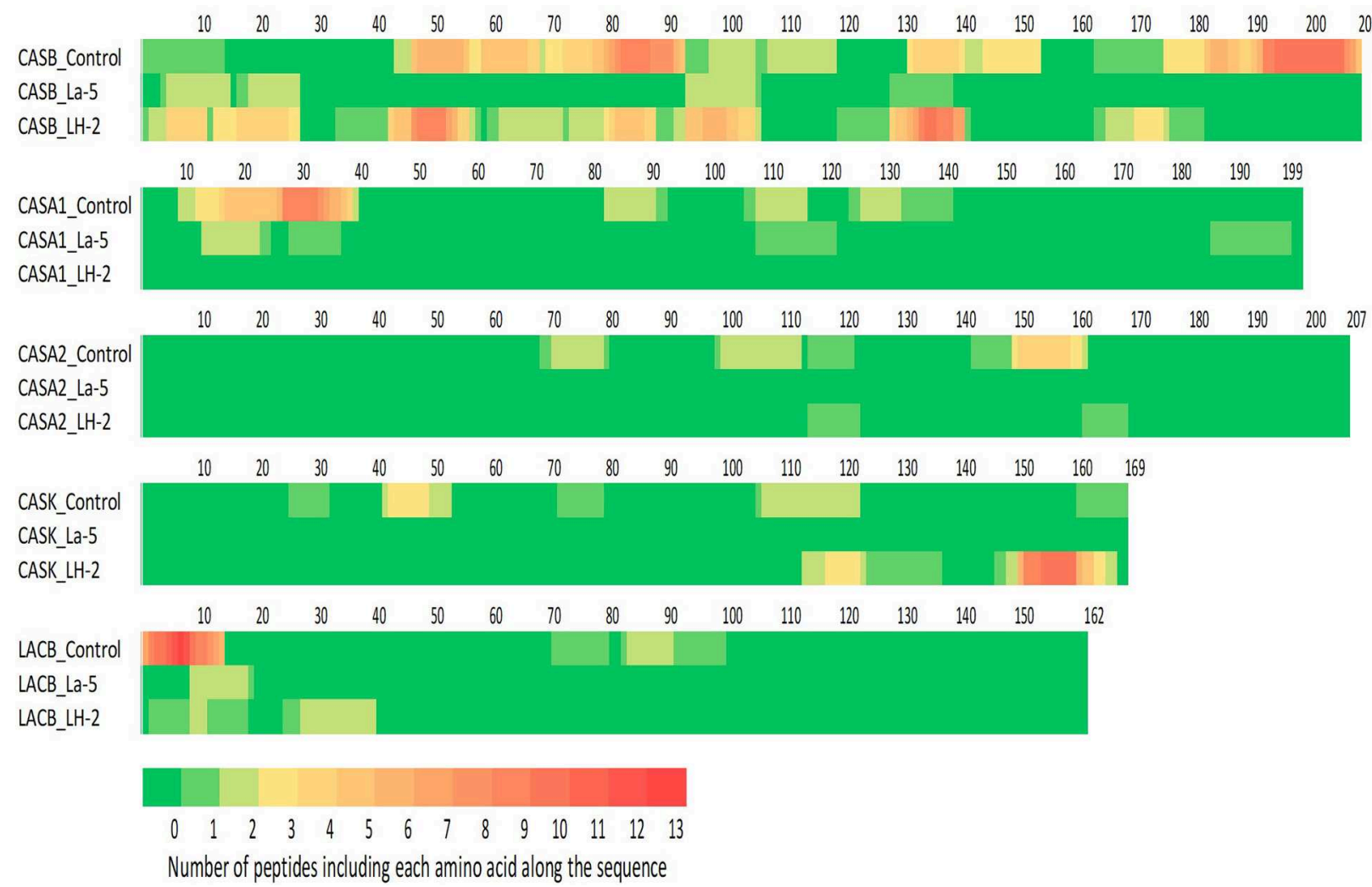

FIGURE 4 | Heat maps of bovine $\beta \beta^{-}, \alpha_{S 1^{-}}, \alpha_{S 2^{-}}, \kappa^{-c a s e i n}$, and $\beta$-lactoglobulin. Each amino acid was colored according to the number of peptides in which this amino acid was found. 

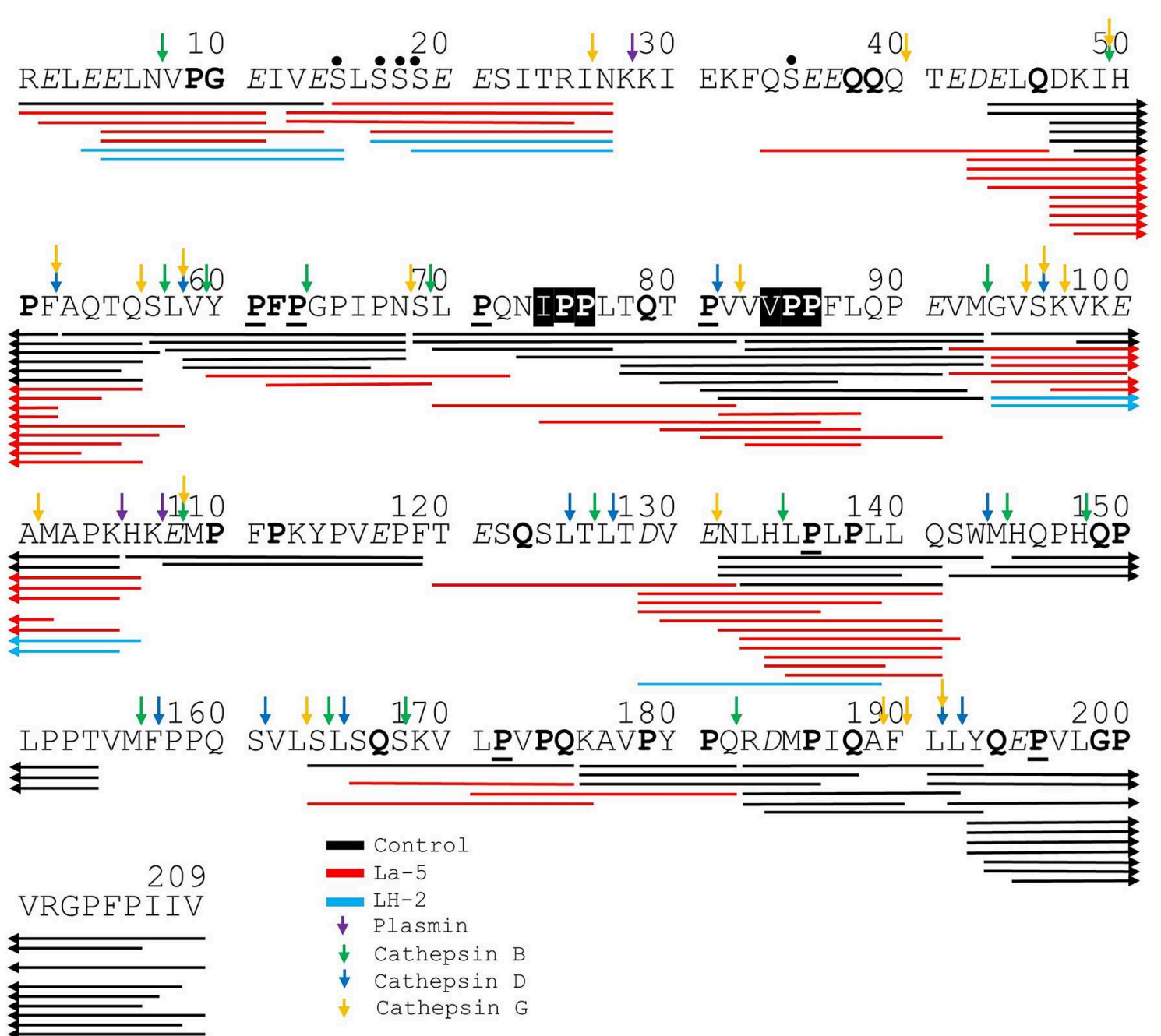

FIGURE 5 | Bovine $\beta$-casein derived peptides identified in non-fermented WPI and WPI fermented with L. helveticus LH-2 and L. acidophilus La-5. Negative charged amino acids (Aspartate D, glutamate E) are in italics, Glycine G, Proline P, and Glutamine Q at position 4, 5, or 6 are marked with bold. P at second position is marked with bold and underline. VPP and IPP are inverse colors (white characters on black background). Phosphorylation sites are marked with a black dot above the serine. Cleavage sites of endogenous milk proteases are adapted from Baum et al. (34) and marked with colored vertical arrows.

The presence of endogenous peptides in unfermented WPI indicates the activity of endogenous milk proteases which are mainly plasmin, elastase and cathepsin D, B, and G (111). Plasmin has little or no activity toward $\kappa$-casein and whey proteins (112), so the presence of endogenous peptides from these proteins in CFSM of L. acidophilus La-5 and L. helveticus LH-2 could be due to the action of other milk proteases such as cathepsin B, D, and G $(34,113)$. Dallas et al. (114) concluded that minimal proteolysis by native milk enzymes continued to function during incubation in the heat-treated milk when compared with that carried out by the proteases of kefir microorganisms which were mainly $L$. acidophilus and L. helveticus. This observation could explain the presence of some peptides shared between the unfermented and fermented WPI. Absence of some peptides after WPI fermentation is likely due to either further hydrolysis by LH-2 and La-5 extracellular proteases or their uptake by these microorganisms. The presence of four shared peptides (three from $\beta$-casein and one from $\beta$-lactoglobulin) in WPI fermented by LH- 2 and La- 5 strains indicates some similarity in the affinity of the proteinases of these strains for certain cleavage sites.

According to peptide analysis data, most of the identified peptides are casein derived, even though whey was used. The presence of casein derived peptides indicates that these proteins were exposed to proteolytic cleavage during processing (115). The three dimensional structure of caseins is more open and flexible than the globular, rigid, compact structures of whey proteins, which make casein proteins more susceptible to the effect of proteases (116).Whey proteins also are not an important peptide precursor during initial fermentation or endogenous proteolysis (117). This could explain why most peptides in the unfermented and fermented WPI media originate from casein proteins. 


\section{$\downarrow \downarrow \downarrow 110 \quad \downarrow 20 \downarrow \downarrow \downarrow \downarrow 30 \quad \downarrow \downarrow \downarrow 40 \quad 50$ \\ RPKHPIKHQG LPQQEVLNENL LRFFVA묘

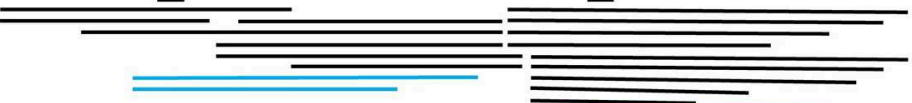

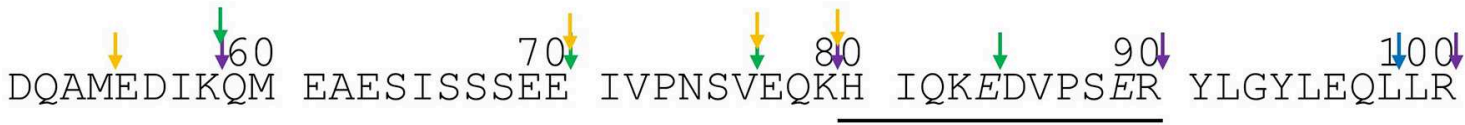
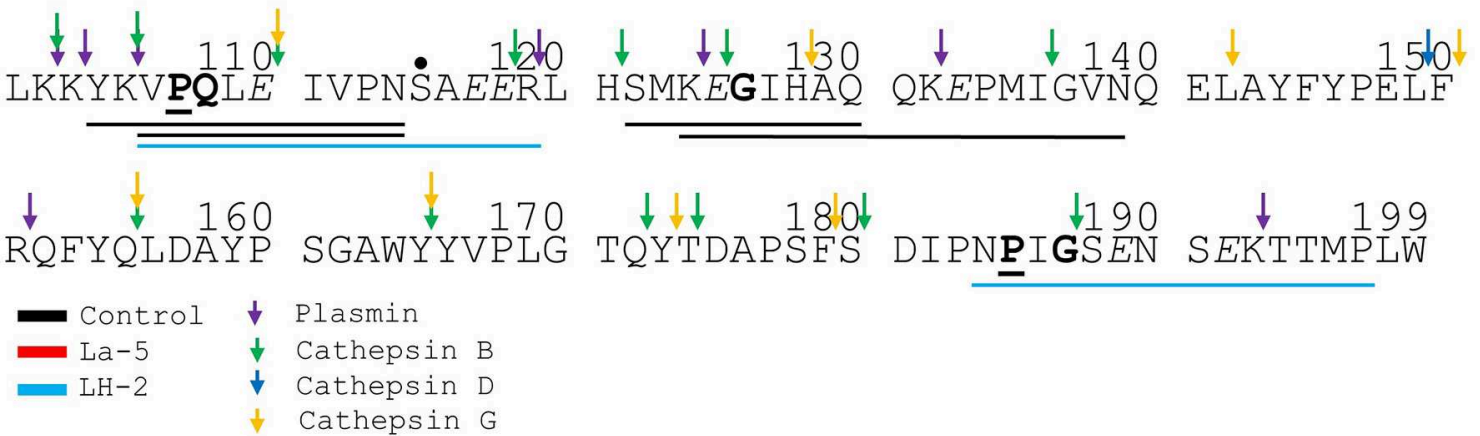

FIGURE 6 | Bovine $\alpha_{\mathrm{S} 1}$-casein derived peptides identified in non-fermented WPI and WPI fermented with L. helveticus LH-2 and L. acidophilus La-5. Negative charged amino acids (Aspartate D, glutamate E) are in italics, Glycine G, Proline P, and Glutamine Q at position 4, 5, or 6 are marked with bold. P at second position is marked with bold and underline. VPP and IPP are inverse colors (white characters on black background). Phosphorylation sites are marked with a black dot above the serine. Cleavage sites of endogenous milk proteases are adapted from Baum et al. (34) and are marked with colored vertical arrows.

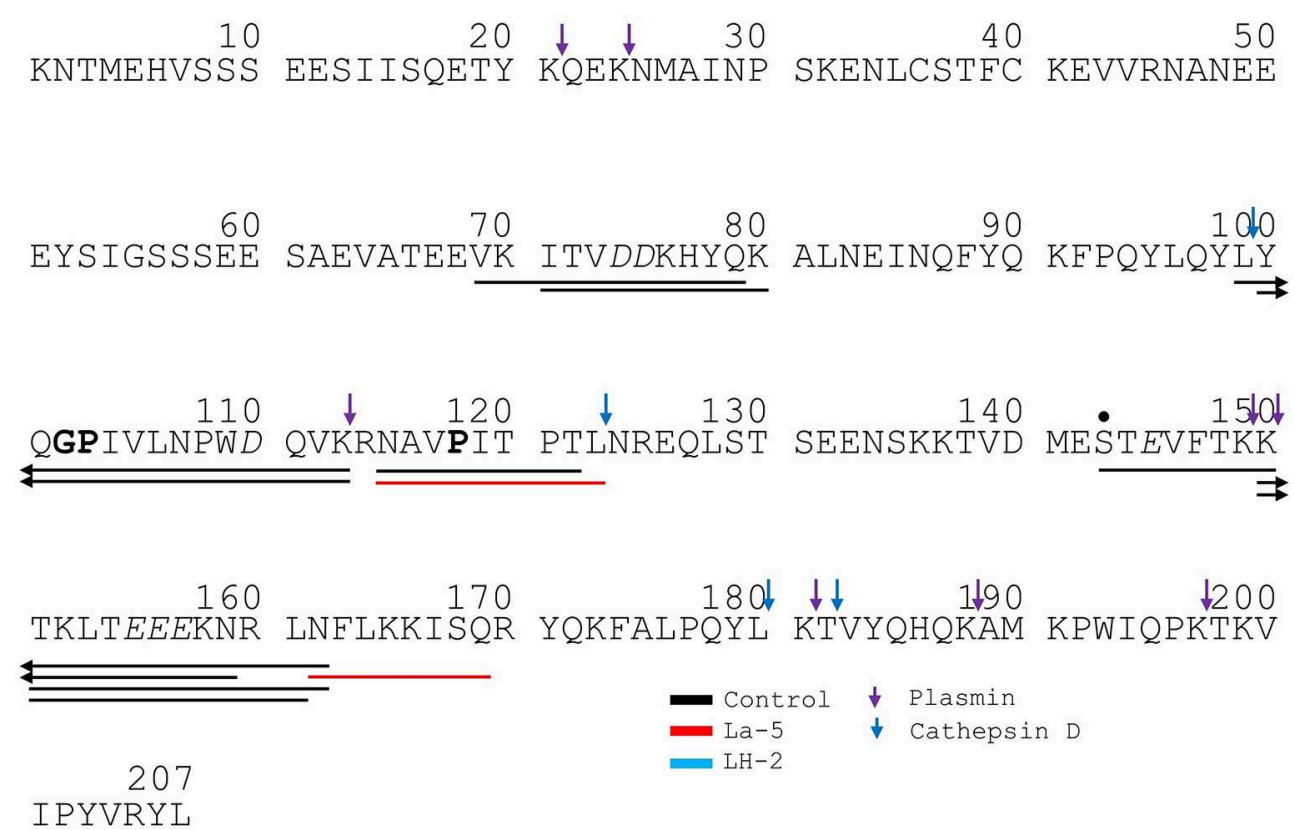

FIGURE 7 | Bovine $\alpha_{\mathrm{S} 2}$-casein derived peptides identified in non-fermented WPI and WPI fermented with L. helveticus LH-2 or L. acidophilus La-5. Negative charged amino acids (Aspartate D, glutamate E) are in italics, Glycine G, Proline P, and Glutamine Q at position 4, 5, or 6 are marked with bold. P at second position is marked with bold and underline. VPP and IPP are inverse colors (white characters on black background). Phosphorylation sites are marked with a black dot above the serine. Cleavage sites of endogenous milk proteases are adapted from Baum et al. (34) and are marked with colored vertical arrows. 


\section{CASK - Variant B2}

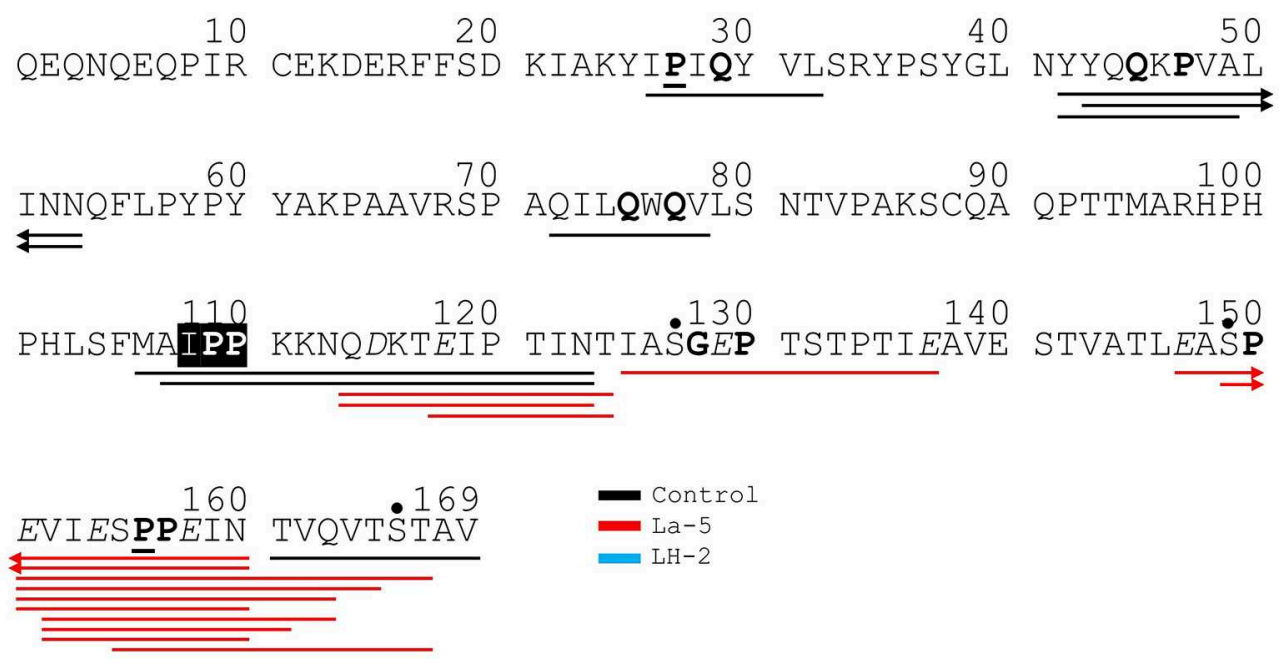

FIGURE 8 | Bovine $\kappa$-casein derived peptides identified in non-fermented control WPI and WPI fermented with $L$. helveticus LH-2 or L. acidophilus La-5. Negative charged amino acids (Aspartate D, glutamate E) are in italics, Glycine G, Proline P, and Glutamine Q at position 4, 5, or 6 are marked with bold. P at second position is marked with bold and underline. VPP and IPP are inverse colors (white characters on black background). Phosphorylation sites are marked with a black dot above the serine. Cleavage sites of endogenous milk proteases are adapted from Hurley et al. (35) and are marked with colored vertical arrows.

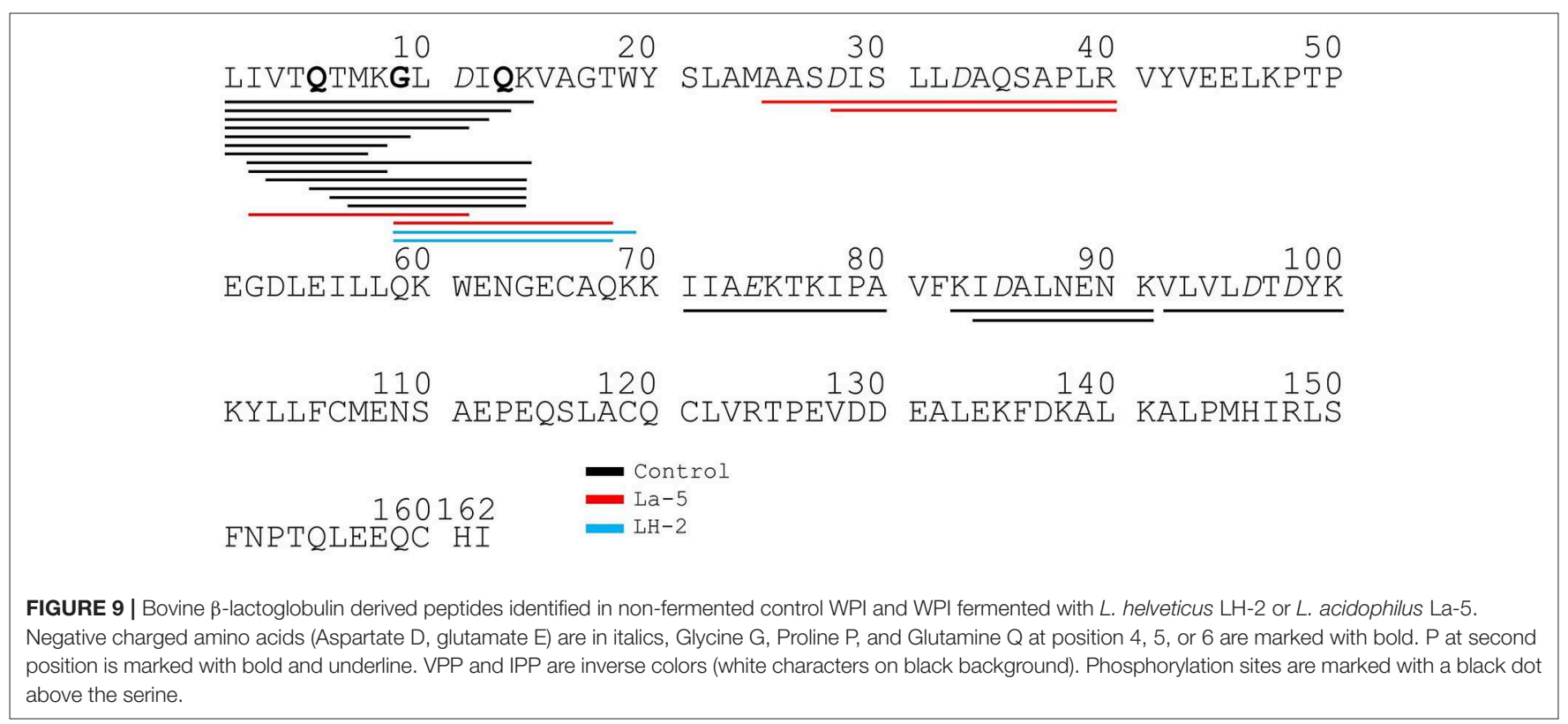

Although $\beta$-casein is not the most abundant protein in casein, our data showed that about half $(47,72$, and 53\%) of identified peptides in the WPI and WPI fermented with LH-2 and La5 , respectively, were derived from $\beta$-casein. Thus, it can be concluded that the endogenous and microbial proteases of LH2 and La- 5 may preferentially attack $\beta$-casein. These findings are consistent with previously studies on bovine casein and kefir (49). The degradation of $\alpha$ s-casein is strain dependent (107). Our results confirm this finding, as La- 5 shows different cleavage sites for $\alpha$ s1-casein while $\alpha$ s1-casein derived peptides were not found after fermentation with LH-2. Nielsen et al. (67) reported no peptides from as1-casein digested with L. helveticus 1198 while Sadat-Mekmene et al. (118) concluded that $\alpha$ s1-casein hydrolysis was enhanced in the presence of both CEPs (prtH, prtH2). The lack of the prtH CEP gene in the L. helveticus LH-2 genome does not explain the absence of $\alpha$ s1-casein derived peptides in LH-2 CFSM, as some of these are present in the control medium. Strain LHC2, which has a similar combination of CEP homologs (PrtH3/PrtH4), does produce peptides from as1-casein within a 3 -h time scale (119). The longer 48-h time scale of the 


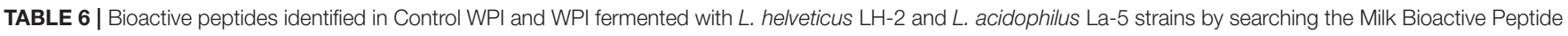
Database with the reported function of the identified peptides.

\begin{tabular}{|c|c|c|c|c|c|c|}
\hline Protein & Peptide & Function & Control & LH-2 & La-5 & References \\
\hline \multirow[t]{38}{*}{ Bovine $\beta-\mathrm{CN}$} & RELEELNVPGEIVE & ACE-inhibitory & $x$ & & & (36) \\
\hline & ELQDKIHPF & ACE-inhibitory & $x$ & & & $(37)$ \\
\hline & SLVYPFPGPIPN & ACE-inhibitory & $x$ & & & (38) \\
\hline & LVYPFPGPIPN & ACE-inhibitory & $x$ & & & (39) \\
\hline & VYPFPGPI & Prolyl endopeptidase-inhibitory & $x$ & & & $(40)$ \\
\hline & WYPFPGPIPN & Antioxidant, ACE-inhibitory & $x$ & & & $(41)$ \\
\hline & SLPQNIPPLTQTPV & ACE-inhibitory & $x$ & & & $(42)$ \\
\hline & SLPQNIPPLTQTPWVPPFLQPEVM & ACE-inhibitory & $x$ & & & $(36)$ \\
\hline & LPQNIPPL & Antidiabetic & $x$ & & & $(43)$ \\
\hline & TQTPWWPPFLQPE & Antioxidant & $x$ & & & $(44)$ \\
\hline & GVSKVKEAMAPK & Antioxidant & $x$ & $X$ & $x$ & $(45)$ \\
\hline & VKEAMAPK & $\begin{array}{l}\text { Antibacterial, } \\
\text { Antioxidant, ACE-inhibitory }\end{array}$ & $x$ & & & $(45-47)$ \\
\hline & HKEMPFPKYPVEPF & Opioid & $x$ & & & $(48)$ \\
\hline & EMPFPKYPVEPF & ACE-inhibitory & $x$ & & & $(49)$ \\
\hline & NLHLPLPLLQ & ACE-inhibitory & $x$ & $x$ & & $(50)$ \\
\hline & MHQPHQPLPPT & Antirotaviral Activity & $x$ & & & $(51)$ \\
\hline & HQPHQPLPPT & Immunomodulatory & $x$ & & & $(52)$ \\
\hline & SLSQSKVLPVPQ & Antioxidant & $x$ & & & $(53)$ \\
\hline & SQSKVLPVPQ & ACE-inhibitory & $x$ & $x$ & & $(54)$ \\
\hline & RDMPIQAF & ACE-inhibitory & $x$ & & & $(42)$ \\
\hline & LLYQEPVLGPVRGPFPIIV & $\begin{array}{l}\text { ACE-inhibitory, Immunomodulatory, } \\
\text { Antithrombin, Antimicrobial }\end{array}$ & $x$ & & & $(55-57)$ \\
\hline & LYQEPVLGPVRGPFPIIV & Mitogen & $x$ & & & $(58)$ \\
\hline & YQEPVLGPVRGPFP & ACE-inhibitory & $x$ & & & $(59)$ \\
\hline & YQEPVLGPVRGPFPI & Antimicrobial & $x$ & & & $(56,60)$ \\
\hline & YQEPVLGPVRGPFPIIV & Immunomodulatory, Antimicrobial & $x$ & & & $(61)$ \\
\hline & QEPVLGPVRGPFPIIV & ACE-inhibitory, Antioxidant & $x$ & & & $(59,62)$ \\
\hline & EPVLGPVRGPFPIIV & ACE-inhibitory & $x$ & & & $(45)$ \\
\hline & DKIHPFA & ACE-inhibitory & & 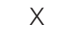 & & (63) \\
\hline & YPFPGPIHNSLPQ & Opioid & & $X$ & & $(64)$ \\
\hline & LPQNIPPLTQTPV & Antidiabetic, ACE-inhibitory & & $x$ & & $(43,65)$ \\
\hline & IPPLTQTPWVPP & ACE-inhibitory & & $X$ & & $(66)$ \\
\hline & TPWPPFL & ACE-inhibitory & & $X$ & & $(37,67)$ \\
\hline & PWVPPFLQPE & Antimicrobial & & $X$ & & $(60)$ \\
\hline & DVENLHLPLPL & ACE-inhibitory & & $X$ & $x$ & (68) \\
\hline & LHLPLPLLQS & ACE-inhibitory & & $X$ & & (69) \\
\hline & HLPLPLLQ & Enteric nervous system development & & $X$ & & (70) \\
\hline & SLSQSKVLPVPQK & Antioxidant & & $X$ & & (53) \\
\hline & LPVPQKAVPYPQ & Antioxidant & & $x$ & & $(71)$ \\
\hline \multirow[t]{4}{*}{ Bovine $\alpha_{s 1}-\mathrm{CN}$} & EVLNENLLRF & ACE-inhibitory & $x$ & & & $(72)$ \\
\hline & FVAPFPEVFGK & ACE-inhibitory & $X$ & & & $(73)$ \\
\hline & VAPFPEVFGKE & ACE-inhibitory & $x$ & & & $(74)$ \\
\hline & VPQLEIVPNSAEER & Mineral carriers, anti-caries activity & & & $x$ & $(75)$ \\
\hline \multirow[t]{3}{*}{ Bovine $\alpha_{\mathrm{S} 2}-\mathrm{CN}$} & LYQGPIVLNPWDQVK & ACE-inhibitory & $x$ & & & $(65)$ \\
\hline & NAVPITPT & ACE-inhibitory & $x$ & & & $(65)$ \\
\hline & NAVPITPTL & Antioxidative & & $X$ & & $(76)$ \\
\hline \multirow[t]{3}{*}{ Bovine $\kappa-\mathrm{CN}$} & YYQQKPVA & Antibacterial & $x$ & & & $(77)$ \\
\hline & MAIPPKKNQDKTEIPTIN & Antithrombotic, Antibacterial & $x$ & & & $(78)$ \\
\hline & TVQVTSTAV & Antibacterial & $x$ & & & $(77,78)$ \\
\hline
\end{tabular}

(Continued) 
TABLE 6 | Continued

\begin{tabular}{|c|c|c|c|c|c|c|}
\hline Protein & Peptide & Function & Control & LH-2 & La-5 & References \\
\hline & EIPTINT & Antibacterial & & $x$ & & (77) \\
\hline & EVIESPPEINTVQVT & ACE-inhibitory, zinc-chelation & & $x$ & & (79) \\
\hline \multirow{4}{*}{ Bovine $\beta$-LG } & LIVTQTMK & Cytotoxic & $x$ & & & (81) \\
\hline & IDALNENK & Antibacterial & $x$ & & & (82) \\
\hline & GLDIQKVAGT & ACE-inhibitory, Antibacterial & & $x$ & $x$ & $(60,85)$ \\
\hline & GLDIQKVAGTW & ACE-inhibitory & & & $x$ & (85) \\
\hline
\end{tabular}

fermentation of WPI by LH-2 may explain the disappearance of as1-casein peptides, and the lack of larger casein proteins in the WPI medium would preclude the release of additional $\alpha$ s1-casein peptides by LH-2. In contrast, LH-2 can produce as2-casein derived peptides while La- 5 cannot produce them. Pescuma et al. (107) reported that $L$. acidophilus strain CRL 636 was unable to degrade as2-casein, which supports the current findings. LH2 shares some $\kappa$-casein cleavage sites with other L. helveticus strains (120) while $\kappa$-casein is poorly degraded by La-5 (105). $\beta$ lactoglobulin is one of the major milk allergens (121). LH-2 and La-5 strains were able to degrade this protein, which indicates the potential of these strains in the production of hypoallergenic dairy products.

Fira et al. (105) reported that the optimal pH for CEP of $L$. acidophilus strains tested was 6.5 with a temperature optimum of $45-50^{\circ} \mathrm{C}$, which might explain the lower number or diversity of peptides produced by La-5 at a lower $\mathrm{pH}$ and temperature ( $\mathrm{pH} 4.5-5.2$ at $37^{\circ} \mathrm{C}$ ). The La-5 genome codes for only one CEP when compared with LH-2, which could result in a lower number or diversity of released peptides accumulating in the growth medium. Even though La-5 produces fewer types of peptides, those that are produced have higher antivirulence activity compare to those produced by $\mathrm{LH}-2$, which depends on the nature and structure of the peptides. None of the peptides found in WPI fermented by La-5 are similar to those found in previous studies of the same strain grown in skim milk (52), which emphasizes the significant effect of growth media on the proteolytic activity of LAB.

Accumulation of peptides with predicted antivirulence effect after fermentation despite the active proteolytic and peptidolytic enzymes of L. helveticus LH-2 and L. acidophilus La-5 may be due to the nature and structure of these peptides. Detmers et al. (122) reported that peptides with hydrophobic and aromatic residues have high binding affinity to OppA, while those with proline, glycine, negatively charged amino acids (Aspartate $\mathrm{D}$, glutamate E) and peptides with neutral or positively charged N-terminal residues having Gly, Pro and/or Gln in position 4, 5 and/or 6 significantly lower the affinity of the peptide for OppA protein. Proline at the second position of a nonameric peptide also resulted in a dramatic drop of the OppA binding affinity (122). Phosphorylated peptides and peptides high in proline content are more resistant to hydrolysis by proteolytic enzymes $(123,124)$.
Oligopeptides containing VPP and IPP sequences could release branched chain amino acids (BCAAs) in the presence of specific peptidases. BCAAs could enhance binding of the Branched Chain Amino Acids Responsive Transcriptional Regulator (BCARR) to DNA sequences in the upstream region of the pepV gene, which would repress the expression of some peptidase genes in L. helveticus (125). Most LH-2 and La-5 peptides found in the supernatant display some of these characteristics, which may help explain their accumulation in the fermented WPI medium.

\section{CONCLUSIONS}

L. helveticus LH-2 and L. acidophilus La-5 produce peptides with antivirulence effect against Salmonella enterica subsp. enterica serovar Typhimurium after growth in whey protein isolate medium. Accumulation of peptides with antivirulence activities may be related to the composition of these peptides and low affinity of these peptides to the oligopeptide-binding protein (OppA) of these strains, thus remaining in the spent medium if they are not transported into the cell. In Salmonella, the antivirulence activity of milk proteinderived peptides is related to the presence of the oppA gene. The undigested and fermented WPI by LH-2 and La-5 strains could be considered as a possible source of natural and functional ingredients, which may be used to increase the biological activity of food products. Further studies are required to explore the antivirulence ability of individual synthetic peptides with the same sequence at different concentrations compared to the antivirulence activity of fermented WPI.

\section{DATA AVAILABILITY STATEMENT}

The datasets generated for this study can be found in the the University of Guelph Research Data Repository [https://doi.org/10.5683/SP2/43M6GX].

\section{AUTHOR CONTRIBUTIONS}

EA carried out the experiments, interpreted the results, and wrote the first draft of the manuscript. SN participated in interpretation 
and presentation of the peptide results. SA-E, AE-L, and ES provided help for interpretation of the results. GL was involved in the design of the study, interpretation of the results, and writing of the manuscript.

\section{FUNDING}

This work was supported and funded by Natural Sciences and Engineering Research Council of Canada (NSERC) Industrial Research Chair (IRCSA 505386-15) held

\section{REFERENCES}

1. Wong MH, Yan M, Chan EW, Biao K, Chen S. Emergence of clinical Salmonella enterica serovar Typhimurium isolates with concurrent resistance to ciprofloxacin, ceftriaxone, and azithromycin. Antimicrob Agents Chemother. (2014) 58:3752-6. doi: 10.1128/AAC.02770-13

2. Rasko DA, Sperandio V. Anti-virulence strategies to combat bacteria-mediated disease. Nat Rev Drug Discov. (2010) 9:117-28. doi: $10.1038 / \mathrm{nrd} 3013$

3. Lavigne JP, Blanc-Potard AB. Molecular evolution of Salmonella enterica serovar Typhimurium and pathogenic Escherichia coli: From pathogenesis to therapeutics. Infect Genet Evol. (2008) 8:217-26. doi: 10.1016/j.meegid.2007.11.005

4. Altier, C. Genetic and environmental control of Salmonella invasion. J Microbiol. (2005) 43:85-92.

5. Lostroh CP, Bajaj V, Lee CA. The cis requirements for transcriptional activation by HilA, a virulence determinant encoded on SPI-1. Mol Microbiol. (2000) 37:300-15. doi: 10.1046/j.1365-2958.2000.01991.x

6. Feng X, Walthers D, Oropeza R, Kenney LJ. The response regulator SsrB activates transcription and binds to a region overlapping OmpR binding sites at Salmonella pathogenicity island 2. Mol Microbiol. (2004) 54:823-35. doi: 10.1111/j.1365-2958.2004.04317.x

7. Nagpal R, Behare P, Rana R, Kumar A, Kumar M, Arora S, et al. Bioactive peptides derived from milk proteins and their health beneficial potentials: an update. Food Funct. (2011) 2:18-27. doi: 10.1039/C0FO0 $0016 \mathrm{G}$

8. Korhonen H. Milk-derived bioactive peptides: from science to applications. J Funct FoodS. (2009) 1:177-87. doi: 10.1016/j.jff.2009.01.007

9. Medellin-Peña MJ, Griffiths MW. Effect of molecules secreted by Lactobacillus acidophilus strain La-5 on Escherichia coli O157:H7 colonization. Appl Environ Microbiol. (2009) 75:1165-72. doi: 10.1128/AEM.01651-08

10. Tellez A, Corredig M, Turner PV, Morales R, Griffiths M. A peptidic fraction from milk fermented with Lactobacillus helveticus protects mice against Salmonella infection. Int Dairy J. (2011) 21:607-14. doi: 10.1016/j.idairyj.2011.03.011

11. Bayoumi MA, Griffiths MW. In vitro inhibition of expression of virulence genes responsible for colonization and systemic spread of enteric pathogens using Bifidobacterium bifidum secreted molecules. Int J Food Microbiol. (2012) 156:255-63. doi: 10.1016/j.ijfoodmicro.2012.03.034

12. Zeinhom M, Tellez AM, Delcenserie V, El-Kholy AM, El-Shinawy SH, Griffiths MW. Yogurt containing bioactive molecules produced by Lactobacillus acidophilus La-5 exerts a protective effect against enterohemorrhagic Escherichia coli in mice. J Food Prot. (2012) 75:1796-805. doi: 10.4315/0362-028X.JFP-11-508

13. López-Fandiño R, Otte J, van Camp J. Physiological, chemical and technological aspects of milk-protein-derived peptides with antihypertensive and ACE-inhibitory activity. Int Dairy J. (2006) 16:1277-93. doi: 10.1016/j.idairyj.2006.06.004

14. Kenny O, FitzGerald RJ, O'Cuinn G, Beresford T, Jordan K. Growth phase and growth medium effects on the peptidase activities of Lactobacillus helveticus. Int Dairy J. (2003) 13:509-16. doi: 10.1016/S0958-6946(03)00073-6 by GL and the Cultural Affairs and Mission Sector in Egypt.

\section{SUPPLEMENTARY MATERIAL}

The Supplementary Material for this article can be found online at: https://www.frontiersin.org/articles/10.3389/fnut.2019. 00152/full\#supplementary-material

Supplementary Table S1 | Information used to identify peptides in unfermented control medium and media fermented by strain La-5 or LH-2.

15. Altermann E, Russell WM, Azcarate-Peril MA, Barrangou R, Buck BL, McAuliffe $\mathrm{O}$, et al. Complete genome sequence of the probiotic lactic acid bacterium Lactobacillus acidophilus NCFM. Proc Natl Acad Sci USA. (2005) 102:3906-12. doi: 10.1073/pnas.0409188102

16. Monnet V. Bacterial oligopeptide-binding proteins. Cell Mol Life Sci. (2003) 60:2100-14. doi: 10.1007/s00018-003-3054-3

17. Goodell EW, Higgins CF. Uptake of cell wall peptides by Salmonella typhimurium and Escherichia coli. J Bacteriol. (1987) 169:3861-5. doi: 10.1128/jb.169.8.3861-3865.1987

18. Bayoumi MA, Griffiths MW. Probiotics down-regulate genes in Salmonella enterica serovar typhimurium pathogenicity islands 1 and 2. J Food Prot. (2010) 73:452-60. doi: 10.4315/0362-028X-73.3.452

19. Guri A, Paligot M, Crvecoeur S, Piedboeuf B, Claes J, Daube G, et al. In vitro screening of mare's milk antimicrobial effect and antiproliverative activity. FEMS Microbiol Lett. (2015) 363:1-7. doi: 10.1093/femsle/fnv234

20. Asakura H, Ekawa T, Sugimoto N, Momose Y, Kawamoto K, Makino SI, et al. Membrane topology of Salmonella invasion protein SipB confers osmotolerance. Biochem Biophys Res Commun. (2012) 426:654-8. doi: 10.1016/j.bbrc.2012.09.012

21. Velayudhan J, Karlinsey JE, Frawley ER, Becker LA, Nartea M, Fang FC. Distinct roles of the Salmonella enterica serovar typhimurium CyaY and YggX proteins in the biosynthesis and repair of iron-sulfur clusters. Infect Immun. (2014) 82:1390-401. doi: 10.1128/IAI.01022-13

22. Botteldoorn N, Van Coillie E, Grijspeerdt K, Werbrouck H, Haesebrouck F, Donné E, et al. Real-time reverse transcription PCR for the quantification of the mntH expression of Salmonella enterica as a function of growth phase and phagosome-like conditions. J Microbiol Methods. (2006) 66:125-35. doi: 10.1016/j.mimet.2005.11.003

23. Pfaffl MW. A new mathematical model for relative quantification in realtime RT-PCR. Nucleic Acids Res. (2001) 29:2002-7. doi: 10.1093/nar/29.9.e45

24. Vandesompele J, De Preter K, Pattyn I, Poppe B, Van Roy N, De Paepe A, et al. Accurate normalization of real-time quantitative RT-PCR data by geometric averaging of multiple internal control genes. Genome Biol. (2002) 3:34-1. doi: 10.1186/gb-2002-3-7-research0034

25. Pfaffl, M. Quantification strategies in real-time PCR. In: A-Z of Quantitative PCR. IUL Biotechnology Series. La Jolla, CA: International University Line Publishers (2004). p. 87-112.

26. Exterkate FA, Alting AC, Bruinenberg PG. Diversity of cell envelope proteinase specificity among strains of Lactococcus lactis and its relationship to charge characteristics of the substrate-binding region. Appl Environ Microbiol. (1993) 59:3640-7.

27. Bradford MM. A rapid and sensitive method for the quantitation of microgram quantities of protein utilizing the principle of protein-dye binding. Anal Biochem. (1976) 72:248-54. doi: 10.1016/0003-2697(76)90527-3

28. Pescuma M, Hébert EM, Mozzi F, Valdez, GFDe. Hydrolysis of whey proteins by Lactobacillus acidophilus, Streptococcus thermophilus and Lactobacillus delbrueckii ssp. bulgaricus grown in a chemically defined medium. J Appl Microbiol. (2007) 103:1738-46. doi: 10.1111/j.1365-2672.2007.03404.x

29. Fernández-Esplá MD, Fox PF, Martín-Hernândez MC. Purification and characterization of a novel serine aminopeptidase from Lactobacillus casei subsp. casei IFPL 731. J Agric Food Chem. (1997) 45:1624-8. doi: $10.1021 /$ jf960889w 
30. Ma B, Zhang K, Hendrie C, Liang C, Li M, Doherty-Kirby A, et al. Peaks: powerful software for peptide de novo sequencing by tandem mass spectrometry. Rapid Commun Mass Spectrom. (2003) 17:2337-42. doi: $10.1002 / \mathrm{rcm} .1196$

31. Medellin-Peña MJ, Wang H, Johnson R, Anand S, Griffiths MW. Probiotics affect virulence-related gene expression in Escherichia coli O157:H7. Appl Environ Microbiol. (2007) 73:4259-67. doi: 10.1128/AEM.00159-07

32. Delcenserie V, LaPointe G, Charaslertrangsi T, Rabalski A, Griffiths MW. Glucose decreases virulence gene expression of Escherichia coli O157:H7. J Food Prot. (2012) 75:748-52. doi: 10.4315/0362-028X.JFP-11-384

33. Broadbent JR, Cai H, Larsen RL, Hughes JE, Welker DL, De Carvalho VG, et al. Genetic diversity in proteolytic enzymes and amino acid metabolism among Lactobacillus helveticus strains1. J Dairy Sci. (2011) 94:4313-28. doi: $10.3168 /$ jds.2010-4068

34. Baum F, Fedorova M, Ebner J, Hoffmann R, Pischetsrieder M. Analysis of the endogenous peptide profile of milk: identification of 248 mainly caseinderived peptides. J Proteome Res. (2013) 12:5447-62. doi: 10.1021/pr4003273

35. Hurley MJ, Larsen LB, Kelly AL, McSweeney PLH. The milk acid proteinase cathepsin D: a review. Int Dairy J. (2000) 10:673-81. doi: 10.1016/S0958-6946(00)00100-X

36. Gobbetti M, Ferranti P, Smacchi E, Goffredi F, Addeo F. Production of angiotensin-I-converting-enzyme-inhibitory peptides in fermented milks started by Lactobacillus delbrueckii subsp. bulgaricus SS1 and Lactococcus lactis subsp. cremoris FT4. Appl Environ Microbiol. (2000) 66:3898-904. doi: 10.1128/AEM.66.9.3898-3904.2000

37. Robert MC, Razaname A, Mutter M, Juillerat MA. Identification of angiotensin-I-converting enzyme inhibitory peptides derived from sodium caseinate hydrolysates produced by Lactobacillus helveticus NCC 2765. J Agric Food Chem. (2004) 52:6923-31. doi: 10.1021/jf049510t

38. Saito T, Nakamura T, Kitazawa H, Kawai Y, Itoh T. Isolation and structural analysis of antihypertensive peptides that exist naturally in gouda cheese. $J$ Dairy Sci. (2000) 83:1434-40. doi: 10.3168/jds.S0022-0302(00)75013-2

39. Miguel M, Gómez-Ruiz JÁ, Recio I, Aleixandre A. Changes in arterial blood pressure after single oral administration of milk-casein-derived peptides in spontaneously hypertensive rats. Mol Nutr Food Res. (2010) 54:1422-7. doi: 10.1002/mnfr.200900448

40. Asano M, Nio N, Ariyoshi Y. Inhibition of prolyl endopeptidase by synthetic beta-casein peptides and their derivatives with a C-terminal prolinol or prolinal. Biosci Biotechnol Biochem. (1992) 56:976-7. doi: 10.1271/bbb.56.976

41. Eisele T, Stressler T, Kranz B, Fischer L. Bioactive peptides generated in an enzyme membrane reactor using Bacillus lentus alkaline peptidase. Eur Food Res Technol. (2013) 236:483-90. doi: 10.1007/s00217-012-1894-5

42. Yamamoto N, Akino A, Takano T. Antihypertensive effect of the peptides derived from casein by an extracellular proteinase from Lactobacillus helveticus CP790. J. Dairy Sci. (1994) 77:917-22. doi: 10.3168/jds.S0022-0302(94)77026-0

43. Uenishi H, Kabuki T, Seto Y, Serizawa A, Nakajima H. Isolation and identification of casein-derived dipeptidyl-peptidase 4 (DPP-4)-inhibitory peptide LPQNIPPL from gouda-type cheese and its effect on plasma glucose in rats. Int Dairy J. (2012) 22:24-30. doi: 10.1016/j.idairyj.2011.08.002

44. Bamdad F, Shin SH, Suh JW, Nimalaratne C, Sunwoo H. Anti-inflammatory and antioxidant properties of casein hydrolysate produced using high hydrostatic pressure combined with proteolytic enzymes. Molecules. (2017) 22:609. doi: 10.3390/molecules22040609

45. Ha GE, Chang OK, Han GS, Ham JS, Park BY, Jeong SG. Comparison of antioxidant activities of hydrolysates of domestic and imported skim milk powders treated with papain. Korean J Food Sci Anim Resour. (2015) 35:360-9. doi: 10.5851/kosfa.2015.35.3.360

46. Korhonen H, Pihlanto A. Technological options for the production of health-promoting proteins and peptides derived from milk and colostrum. Curr Pharm Des. (2007) 13:829-43. doi: 10.2174/138161207780363112

47. Sedaghati M, Ezzatpanah H, Boojar MMA, Ebrahimi MT, Kobarfard F. Isolation and identification of some antibacterial peptides in the plasmin-digest of $\beta$-casein. LWT Food Sci. Technol. (2016) 68:217-25. doi: 10.1016/j.lwt.2015.12.019

48. Plaisancié P, Claustre J, Estienne M, Henry G, Boutrou R, Paquet A, et al. A novel bioactive peptide from yoghurts modulates expression of the gel-forming MUC2 mucin as well as population of goblet cells and
Paneth cells along the small intestine. J Nutr Biochem. (2013) 24:213-21. doi: 10.1016/j.jnutbio.2012.05.004

49. Liu Y, Pischetsrieder M. Identification and relative quantification of bioactive peptides sequentially released during simulated gastrointestinal digestion of commercial kefir. J Agric Food Chem. (2017) 65:1865-73. doi: 10.1021/acs.jafc.6b05385

50. Miguel M, Recio I, Ramos M, Delgado M, Aleixandre M. Antihypertensive effect of peptides obtained from Enterococcus faecalis-fermented milk in rats. J. Dairy Sci. (2006) 89:3352-9. doi: 10.3168/jds.S0022-0302(06)72372-4

51. Chenoll E, Casinos B, Bataller E, Buesa J, Ramón D, Genovés S, et al. Identification of a peptide produced by Bifidobacterium longum CECT 7210 with antirotaviral activity. Front Microbiol. (2016) 7:655. doi: $10.3389 /$ fmicb. 2016.00655

52. Tellez A, Corredig M, Brovko LY, Griffiths MW. Characterization of immune-active peptides obtained from milk fermented by Lactobacillus helveticus. J Dairy Res. (2010) 77:129. doi: 10.1017/S002202990999046X

53. Hernandez-Ledesma B, Amigo L, Ramos M, Recio I. Angiotensin converting enzyme inhibitory activity in commercial fermented products. formation of peptides under simulated gastrointestinal digestion. J Agric Food Chem. (2004) 52:1504-10. doi: 10.1021/jf034997b

54. Hayes M, Stanton C, Slattery H, O'Sullivan O, Hill C, Fitzgerald GF, et al. Casein fermentate of Lactobacillus animalis DPC6134 contains a range of novel propeptide angiotensin-converting enzyme inhibitors. Appl Environ Microbiol. (2007) 73:4658-67. doi: 10.1128/AEM.00096-07

55. Bonomi F, Brandt R, Favalli S, Ferranti P, Fierro O, Frøkiær H, et al. Structural determinants of the immunomodulatory properties of the C-terminal region of bovine $\beta$-casein. Int Dairy J. (2011) 21:770-6. doi: 10.1016/j.idairyj.2011.04.012

56. Birkemo GA, O'Sullivan O, Ross RP, Hill C. Antimicrobial activity of two peptides casecidin 15 and 17, found naturally in bovine colostrum. J Appl Microbiol. (2009) 106:233-40. doi: 10.1111/j.1365-2672.2008.03996.x

57. Rojas-Ronquillo R, Cruz-Guerrero A, Flores-Nájera A, Rodríguez-Serrano G, Gómez-Ruiz L, Reyes-Grajeda JP, et al. Antithrombotic and angiotensinconverting enzyme inhibitory properties of peptides released from bovine casein by Lactobacillus casei Shirota. Int Dairy J. (2012) 26:147-54. doi: 10.1016/j.idairyj.2012.05.002

58. Coste M, Rochet V, Léonil J, Mollé D, Bouhallab S, Tomé D. Identification of C-terminal peptides of bovine $\beta$-casein that enhance proliferation of rat lymphocytes. Immunol Lett. (1992) 33:41-6. doi: 10.1016/0165-2478(92)90091-2

59. Ha GE, Chang OK, Jo SM, Han GS, Park BY, Ham JS, et al. Identification of antihypertensive peptides derived from low molecular weight casein hydrolysates generated during fermentation by Bifidobacterium longum KACC 91563. Korean J Food Sci Anim Resour. (2015) 35:738-47. doi: 10.5851/kosfa.2015.35.6.738

60. Almaas H, Eriksen E, Sekse C, Comi I, Flengsrud R, Holm H, et al. Antibacterial peptides derived from caprine whey proteins, by digestion with human gastrointestinal juice. Br J Nutr. (2011) 106:896-905. doi: $10.1017 /$ S0007114511001085

61. Silva SV, Malcata FX. Caseins as source of bioactive peptides. Int Dairy J. (2005) 15:1-15. doi: 10.1016/j.idairyj.2004.04.009

62. Sabeena Farvin KH, Baron CP, Nielsen NS, Otte J, Jacobsen C. Antioxidant activity of yoghurt peptides: Part 2 - Characterisation of peptide fractions. Food Chem. (2010) 123:1090-7. doi: 10.1016/j.foodchem.2010.05.029

63. Quirós A, Hernández-Ledesma B, Ramos M, Amigo L, Recio I. Angiotensinconverting enzyme inhibitory activity of peptides derived from caprine kefir. J Dairy Sci. (2005) 88:3480-7. doi: 10.3168/jds.S0022-0302(05)73032-0

64. Rokka T, Syväoja EL, Tuominen J, Korhonen H. Release of bioactive peptides by enzymatic proteolysis of Lactobacillus GG fermented UHT milk. Milchwissenschaft. (1997) 52:675-7.

65. Nongonierma AB, Mazzocchi C, Paolella S, FitzGerald RJ. Release of dipeptidyl peptidase IV (DPP-IV) inhibitory peptides from milk protein isolate (MPI) during enzymatic hydrolysis. Food Res Int. (2017) 94:79-89. doi: 10.1016/j.foodres.2017.02.004

66. Nakamura Y, Yamamoto N, Sakai K, Okubo A, Yamazaki S, Takano T. Purification and characterization of angiotensin I-converting enzyme inhibitors from sour milk. J Dairy Sci. (1995) 78:777-83. doi: $10.3168 /$ jds.S0022-0302(95)76689-9 
67. Nielsen MS, Martinussen T, Flambard B, Sørensen KI, Otte J. Peptide profiles and angiotensin-I-converting enzyme inhibitory activity of fermented milk products: Effect of bacterial strain, fermentation $\mathrm{pH}$, and storage time. Int Dairy J. (2009) 19:155-65. doi: 10.1016/j.idairyj.2008.10.003

68. Qureshi TM, Vegarud GE, Abrahamsen RK, Skeie S. Characterization of the Norwegian autochthonous cheese Gamalost and its angiotensin I-converting enzyme (ACE) inhibitory activity during ripening. Dairy Sci Technol. (2012) 92:613-25. doi: 10.1007/s13594-012-0078-1

69. García-Tejedor A, Sánchez-Rivera L, Recio I, Salom JB, Manzanares P. Dairy Debaryomyces hansenii strains produce the antihypertensive casein-derived peptides LHLPLP and HLPLP. LWT Food Sci Technol. (2015) 61:550-6. doi: 10.1016/j.lwt.2014.12.019

70. Cossais F, Clawin-Rädecker I, Lorenzen PC, Klempt M. Short communication: Tryptic $\beta$-casein hydrolysate modulates enteric nervous system development in primary culture. J Dairy Sci. (2017) 100:3396-403. doi: 10.3168 /jds.2016-11440

71. Rival SG, Boeriu CG, Wichers HJ. Caseins and casein hydrolysates. 2. Antioxidative properties and relevance to lipoxygenase inhibition. J Agric Food Chem. (2001) 49:295-302. doi: 10.1021/jf0003911

72. Torres-Llanez MJ, González-Córdova F, Hernandez-Mendoza A, Garcia HS, Vallejo-Cordoba B. Angiotensin-converting enzyme inhibitory activity in Mexican Fresco cheese. J. Dairy Sci. (2011) 94:3794-800. doi: 10.3168/jds.2011-4237

73. Ong L, Shah NP. Release and identification of angiotensin-converting enzyme-inhibitory peptides as influenced by ripening temperatures and probiotic adjuncts in Cheddar cheeses. LWT Food Sci Technol. (2008) 41:1555-66. doi: 10.1016/j.lwt.2007.11.026

74. del Mar Contreras M, Carrón R, Montero MJ, Ramos M, Recio, I. Novel casein-derived peptides with antihypertensive activity. Int Dairy J. (2009) 19:566-73. doi: 10.1016/j.idairyj.2009.05.004

75. Smacchi E, Gobbetti, M. Bioactive peptides in dairy products: synthesis and interaction proteolytic enzymes. Food Microbiol. (2000) 17:129-41. doi: 10.1006/fmic.1999.0302

76. Shanmugam VP, Kapila S, Sonfack TK, Kapila R. Antioxidative peptide derived from enzymatic digestion of buffalo casein. Int Dairy J. (2015) 42:1-5. doi: 10.1016/j.idairyj.2014.11.001

77. López-Expósito I, Minervini F, Amigo L, And Recio I. Identification of Antibacterial Peptides from Bovine к-Casein. J Food Prot. (2006) 69:2992-7. doi: 10.4315/0362-028X-69.12.2992

78. Rizzello CG, Losito I, Gobbetti M, Carbonara T, De Bari MD, Zambonin PG. Antibacterial activities of peptides from the watersoluble extracts of Italian cheese varieties. J Dairy Sci. (2005) 88:2348-60. doi: 10.3168/jds.S0022-0302(05)72913-1

79. Daliri EBM, Lee BH, Park BJ, Kim SH, Oh DH. Antihypertensive peptides from whey proteins fermented by lactic acid bacteria. Food Sci Biotechnol. (2018) 27:1781-9. doi: 10.1007/s10068-018-0423-0

80. Power O, Fernández A, Norris R, Riera FA, FitzGerald RJ. Selective enrichment of bioactive properties during ultrafiltration of a tryptic digest of $\beta$-lactoglobulin. J Funct Foods. (2014) 9:38-47. doi: 10.1016/j.jff.2014.04.002

81. Jacquot A, Gauthier SF, Drouin R, Boutin Y. Proliferative effects of synthetic peptides from $\beta$-lactoglobulin and $\alpha$-lactalbumin on murine splenocytes. Int Dairy J. (2010) 20:514-21. doi: 10.1016/j.idairyj.2010.02.013

82. Sedaghati M, Ezzatpanah H, Boojar MMA, Ebrahimi MT, Aminafshar M. Plasmin-digest of $\beta$-lactoglobulin with antibacterial properties. Food Agric. Immunol. (2015) 26:218-30. doi: 10.1080/09540105.2014.893998

83. Silveira ST, Martínez-Maqueda D, Recio I, Hernández-Ledesma B. Dipeptidyl peptidase-IV inhibitory peptides generated by tryptic hydrolysis of a whey protein concentrate rich in $\beta$-lactoglobulin. Food Chem. (2013) 141:1072-7. doi: 10.1016/j.foodchem.2013.03.056

84. López Expósito I, Recio I. Antibacterial activity of peptides and folding variants from milk proteins. Int Dairy J. (2006) 16:1294-305. doi: 10.1016/j.idairyj.2006.06.002

85. Pihlanto-Leppälä A, Rokka T, Korhonen H. Angiotensin I converting enzyme inhibitory peptides derived from bovine milk proteins. Int Dairy J. (1998) 8:325-31. doi: 10.1016/S0958-6946(98)00048-X

86. Brovko LY, Vandenende C, Chu B, Ng K-Y, Brooks A, Griffiths MW. In vivo assessment of effect of fermented milk diet on course of infection in mice with bioluminescent Salmonella. J Food Prot. (2003) 66:2160-3. doi: 10.4315/0362-028X-66.11.2160

87. Vinderola G, Matar C, Perdigón G. Milk fermented by Lactobacillus helveticus R389 and its non-bacterial fraction confer enhanced protection against Salmonella enteritidis serovar Typhimurium infection in mice. Immunobiology. (2007) 212:107-18. doi: 10.1016/j.imbio.2006.09.003

88. Bondue P, Crèvecoeur S, Brose F, Daube G, Seghaye MC, Griffiths MW, et al. Cell-free spent media obtained from Bifidobacterium bifidum and Bifidobacterium crudilactis grown in media supplemented with 3'-sialyllactose modulate virulence gene expression in Escherichia coli O157: H7 and Salmonella Typhimurium. Front Microbiol. (2016) 7:1460. doi: $10.3389 /$ fmicb. 2016.01460

89. Rumbaugh KP. Convergence of hormones and autoinducers at the host/pathogen interface. Anal Bioanal Chem. (2007) 387:425-35. doi: 10.1007/s00216-006-0694-9

90. Andrews JC, Blevins TC, Short SA. Regulation of peptide transport in Escherichia coli: Induction of the trp-linked operon encoding the oligopeptide permease. J Bacteriol. (1986) 165:428-33. doi: $10.1128 /$ jb.165.2.428-433.1986

91. Claverys JP, Grossiord B, Alloing G. Is the Ami-Alia/B oligopeptide permease of Streptococcus pneumoniae involved in sensing environmental conditions? Res Microbiol. (2000) 151:457-63. doi: 10.1016/S0923-2508(00)00169-8

92. Baek $\mathrm{CH}$, Wang S, Roland KL, Curtiss R. Leucine-responsive regulatory protein (Lrp) acts as a virulence repressor in Salmonella enterica serovar typhimurium. J Bacteriol. (2009) 191:1278-92. doi: 10.1128/JB.01142-08

93. Savijoki K, Ingmer H, Varmanen P. Proteolytic systems of lactic acid bacteria. Appl Microbiol Biotechnol. (2006) 71:394-406. doi: 10.1007/s00253-006-0427-1

94. Pederson JA, Mileski GJ, Weimer BC, Steele JL. Genetic characterization of a cell envelope-associated proteinase from Lactobacillus helveticus CNRZ32. J Bacteriol. (1999) 181:4592-7.

95. Genay M, Sadat L, Gagnaire V, Lortal S. PrtH2, Not prtH, Is the ubiquitous cell wall proteinase gene in Lactobacillus helveticus. Appl Environ Microbiol. (2009) 75:3238-49. doi: 10.1128/AEM.02395-08

96. Sadat-Mekmene L, Genay M, Atlan D, Lortal S, Gagnaire V. Original features of cell-envelope proteinases of Lactobacillus helveticus. A review. Int J Food Microbiol. (2011) 146:1-13. doi: 10.1016/j.ijfoodmicro.2011.01.039

97. Zhao W, Chen Y, Sun Z, Wang J, Zhou Z, Sun T, et al. Complete genome sequence of Lactobacillus helveticus H10. J Bacteriol. (2011) 193:2666-7. doi: 10.1128/JB.00166-11

98. Doeven MK, Kok J, Poolman B. Specificity and selectivity determinants of peptide transport in Lactococcus lactis and other microorganisms. Mol Microbiol. (2005) 57:640-9. doi: 10.1111/j.1365-2958.2005.04698.x

99. Liu M, Bayjanov JR, Renckens B, Nauta A, Siezen RJ. The proteolytic system of lactic acid bacteria revisited : a genomic comparison. BMC Genomics. (2010) 11:36. doi: 10.1186/1471-2164-11-36

100. Azcarate-Peril MA, Mcauliffe O, Altermann E, Lick S, Russell WM, Klaenhammer TR. Microarray analysis of a two-component regulatory system involved in acid resistance and proteolytic activity in Lactobacillus acidophilus. Society. (2005) 71:5794-804. doi: 10.1128/AEM.71.10.5794-5804.2005

101. Azcarate-Peril Ma, Tallon R, Klaenhammer TR. Temporal gene expression and probiotic attributes of Lactobacillus acidophilus during growth in milk. J Dairy Sci. (2009) 92:870-86. doi: 10.3168/jds.200 8-1457

102. Yamamoto N, Akino A, Takano T. Purification and specificity of a cell-wallassociated proteinase from Lactobacillus helveticus CP790. J Biochem. (1993) 114:740-5. doi: 10.1093/oxfordjournals.jbchem.a124247

103. Martín-Hernández MC, Alting AC, Exterkate FA. Purification and characterization of the mature, membrane-associated cell-envelope proteinase of Lactobacillus helveticus L89. Appl Microbiol Biotechnol. (1994) 40:828-34. doi: 10.1007/BF00173983

104. Miyamoto M, Ueno HM, Watanabe M, Tatsuma Y, Seto Y, Miyamoto $\mathrm{T}$, et al. Distinctive proteolytic activity of cell envelope proteinase of Lactobacillus helveticus isolated from airag, a traditional Mongolian fermented mare's milk. Int J Food Microbiol. (2015) 197:65-71. doi: 10.1016/j.ijfoodmicro.2014.12.012 
105. Fira D, Kojic M, Banina A, Spasojevic I, Strahinic I, Topisirovic L. Characterization of cell envelope-associated proteinases of thermophilic lactobacilli. J Appl Microbiol. (2001) 90:123-30. doi: 10.1046/j.1365-2672.2001.01226.x

106. Beganović J, Kos B, Leboš Pavunc A, Uroić K, DŽidara P, Šušković J. Proteolytic activity of probiotic strain Lactobacillus helveticus M92. Anaerobe. (2013) 20:58-64. doi: 10.1016/j.anaerobe.201 3.02 .004

107. Pescuma M, Espeche Turbay MB, Mozzi F, De Valdez GF, De Giori GS, Hebert EM. Diversity in proteinase specificity of thermophilic lactobacilli as revealed by hydrolysis of dairy and vegetable proteins. Appl Microbiol Biotechnol. (2013) 97:7831-44. doi: 10.1007/s00253-0135037-0

108. Hebert EM, Mamone G, Picariello G, Raya RR, Savoy G, Ferranti P, et al. Characterization of the pattern of alphas1- and beta-casein breakdown and release of a bioactive peptide by a cell envelope proteinase from Lactobacillus delbrueckii subsp. lactis CRL 581. Appl Environ Microbiol. (2008) 74:3682-9. doi: 10.1128/AEM.00247-08

109. Hebert EM, Raya RR, De Giori GS. Nutritional requirements and nitrogen-dependent regulation of proteinase activity of Lactobacillus helveticus CRL 1062. Appl Environ Microbiol. (2000) 66:5316-21. doi: 10.1128/AEM.66.12.5316-5321.2000

110. Meijer W, Marugg JD, Hugenholtz J. Regulation of proteolytic enzyme activity in lactococcus lactis. Appl Environ Microbiol. (1996) 62:156-61.

111. Dallas DC, Weinborn V, de Moura Bell JMLN, Wang M, Parker EA, Guerrero A, et al. Comprehensive peptidomic and glycomic evaluation reveals that sweet whey permeate from colostrum is a source of milk protein-derived peptides and oligosaccharides. Food Res Int. (2014) 63:2039. doi: 10.1016/j.foodres.2014.03.021

112. Yamamoto $\mathrm{N}$, Ono $\mathrm{H}$, Maeno $\mathrm{M}$, Ueda $\mathrm{Y}$, Takano $\mathrm{T}$, Momose $\mathrm{H}$. Classification of Lactobacillus helveticus strains by immunological differences in extracellular proteinases. Biosci Biotechnol Biochem. (1998) 62:1228-30. doi: $10.1271 /$ bbb. 62.1228

113. Considine T, Healy Á, Kelly AL, McSweeney PLH. Hydrolysis of bovine caseins by cathepsin $\mathrm{B}$, a cysteine proteinase indigenous to milk. Int Dairy J. (2004) 14:117-24. doi: 10.1016/S0958-6946(03)00171-7

114. Dallas DC, Citerne F, Tian T, Silva VLM, Kalanetra KM, Frese $\mathrm{SA}$, et al. Peptidomic analysis reveals proteolytic activity of kefir microorganisms on bovine milk proteins. Food Chem. (2016) 197:273-84. doi: 10.1016/j.foodchem.2015.10.116

115. Dallas DC, Guerrero A, Parker EA, Garay LA, Bhandari A, Lebrilla CB, et al. Peptidomic profile of milk of Holstein cows at peak lactation. J Agric Food Chem. (2014) 62:58-65. doi: 10.1021/jf4040964

116. Dallas DC, Guerrero A, Khaldi N, Castillo PA, Martin WF, Smilowitz JT, et al. Extensive in vivo human milk peptidomics reveals specific proteolysis yielding protective antimicrobial peptides. J Proteome Res. (2013) 12:2295304. doi: $10.1021 /$ pr400212z
117. Ebner J, Așçi Arslan A, Fedorova M, Hoffmann R, Küçükçetin A, Pischetsrieder M. Peptide profiling of bovine kefir reveals 236 unique peptides released from caseins during its production by starter culture or kefir grains. J Proteomics. (2015) 117:41-57. doi: 10.1016/j.jprot.2015.01.005

118. Sadat-Mekmene L, Jardin J, Corre C, Mollé D, Richoux R, Delage MM, et al. Simultaneous presence of $\mathrm{PrtH}$ and $\mathrm{PrtH} 2$ proteinases in Lactobacillus helveticus strains improves breakdown of the pure as1-casein. Appl Environ Microbiol. (2011) 77:179-86. doi: 10.1128/AEM.01466-10

119. Jensen MP, Vogensen FK, Ardö Y. Variation in caseinolytic properties of six cheese related Lactobacillus helveticus strains. Int Dairy J. (2009) 19:661-8. doi: 10.1016/j.idairyj.2009.04.001

120. Scolari G, Vescovo M, Zacconi C, Vescovi F. Extraction and partial characterization of proteolytic activities from the cell surface of Lactobacillus helveticus Zuc2. J Dairy Sci. (2006) 89:3800-9. doi: 10.3168/jds.S0022-0302(06)72421-3

121. Picariello G, Mamone G, Addeo F, Ferranti P. The frontiers of mass spectrometry-based techniques in food allergenomics. J Chromatogr A. (2011) 1218:7386-98. doi: 10.1016/j.chroma.2011.06.033

122. Detmers FJ, Lanfermeijer FC, Abele R, Jack RW, Tampe R, Konings WN, et al. Combinatorial peptide libraries reveal the ligand-binding mechanism of the oligopeptide receptor OppA of Lactococcus lactis. Proc Natl Acad Sci USA. (2000) 97:12487-92. doi: 10.1073/pnas.220308797

123. Deutsch SM, Molle D, Gagnaire V, Piot M, Atlan D, Lortal S. Hydrolysis of sequenced $\beta$-casein peptides provides new insight into peptidase activity from thermophilic lactic acid bacteria and highlights intrinsic resistance of phosphopeptides. Appl Environ Microbiol. (2000) 66:5360-7. doi: 10.1128/AEM.66.12.5360-5367.2000

124. Algaron F, Miranda G, Le Bars D, Monnet V. Milk fermentation by Lactococcus lactis with modified proteolytic systems to accumulate potentially bio-active peptides. Lait. (2004) 84:115-23. doi: 10.1051/lait:2003034

125. Wakai T, Yamamoto N. A novel branched chain amino acids responsive transcriptional regulator, BCARR, negatively acts on the proteolytic system in Lactobacillus helveticus. PLoS ONE. (2013) 8:e75976. doi: 10.1371/journal.pone.0075976

Conflict of Interest: The authors declare that the research was conducted in the absence of any commercial or financial relationships that could be construed as a potential conflict of interest.

Copyright (c) 2019 Ali, Nielsen, Abd-El Aal, El-Leboudy, Saleh and LaPointe. This is an open-access article distributed under the terms of the Creative Commons Attribution License (CC BY). The use, distribution or reproduction in other forums is permitted, provided the original author(s) and the copyright owner(s) are credited and that the original publication in this journal is cited, in accordance with accepted academic practice. No use, distribution or reproduction is permitted which does not comply with these terms. 